\title{
Recent advances in genetic manipulation of crops: A promising approach to address the global food and industrial applications
}

\author{
Nirmala Nalluri \& Vasavi Rama Karri* \\ Department of Biotechnology, GITAM Institute of Technology, GITAM (Deemed to be University), Visakhapatnam 530 045, Andhra Pradesh, India
}

\section{Article history}

Received: 20 November 2019 Accepted: 17 December 2019 Published: 08 January 2020

\section{Publisher}

Horizon e-Publishing Group

\footnotetext{
*Correspondence

Vasavi Rama Karri

四 vasavi8@gmail.com
}

\begin{abstract}
Continuous increase in world's population demands high food production, which has become a major challenge to the humanity. When there is sufficient amount of nutritious food to all the people there will be no problem of food scarcity. So, to increase the food production, many countries are adopting strategies of genetic engineering to enhance the crop yield. Recombinant DNA technology can be a viable source to develop genetically modified crops with enhanced resistance and improved yields to fight against malnutrition and food scarcity. With this technology, selected traits can be inserted into the plant genome, unlike traditional plant breeding, where many characters of two different crops will be combined which may lead to genetic modification at an extensive level. Present review focuses on the methods of plant transformation and outlines the scope of genetic transformation for improved crop production by transferring selected genes for biotic and abiotic stress tolerance. In addition, current study also provides information about various genetically modified crops produced worldwide and their commercialization towards various biotechnological products like GM livestock, GM microorganisms, vaccines and industrial products like bio-plastic produced from the transgenic plants.
\end{abstract}

Keywords: Biotechnology; Crop improvement; Plant transformation; Recombinant DNA Technology; Transgenic crops

Citation: Nalluri N, Karri V R. Recent advances in genetic manipulation of crops: A promising approach to address the global food and industrial applications. Plant Science Today 2020;7(1):70-92. https://doi.org/10.14719/pst.2020.7.1.659

Copyright: (C) Nalluri \& Karri (2020). This is an open-access article distributed under the terms of the Creative Commons Attribution License, which permits unrestricted use, distribution, and reproduction in any medium, provided the original author and source are credited (https://creativecommons.org/licenses/by/4.0/).

Indexing: Plant Science Today is covered by Scopus, Web of Science, BIOSIS Previews, ESCI, CAS, AGRIS, UGC-CARE, CABI, Google Scholar, etc. Full list at http://www.plantsciencetoday.online

\section{Introduction}

Since many years, plants with desirable characteristics were being produced by employing conventional breeding methods. In this process, desirable traits will be selected, combined and propagated by continuous crossing for various generations and is a very long method, which takes up to 15 years to produce new varieties with desired characters (1). Based on the present conditions, traditional methods solely will not be sufficient to supply required food, fuel and fiber to overcome the future demands. In this approach, genetic engineering plays an important role in 
increasing the productivity similar to the period of green revolution during 1960 s to 1980 s, which brought a great change in rural incomes and this idea is about three decades old (2). The advantage of these techniques related to the traditional breeding methods is, they not only efficiently expedite in a highly focused manner by inserting particular genes, but also prevailed the limit of sexual variance between different plant species and immensely raise the available gene pool (3). By adopting the strategy of genetic engineering, rural poverty can be decreased by increasing the food production and it encircles all aspects of agricultural production that includes high crop yield, less fertilizer and pesticide applications, increase in quality, simple processing and improved storage, better quality of the products and modern technologies to examine the condition of plants.

This field further encircles a broad range of technologies and can be used for a wide range of purposes, like generation of new plant varieties and animal communities to increase their yields, development of disease and insect resistant varieties, abiotic stress tolerant varieties, diagnosis of plant or animal diseases, increasing the livestock feed and production of plant based vaccines (4-15). Commercial transgenic crops with desired traits can be developed by the insertion of one or more new genes along with regulatory sequences or by down regulating the internal genes (16). In plant biotechnology, to control the gene expression various methods like RNA sequencing could be used (17) and in this orientation various synthetic promoters, repressors and enhancers were developed by the scientists for innate and transgenes expression regulation.

With the study of DNA structure and its replication in 1950s, research on the alteration of the genetic material was increased and the first recombinant DNA molecule was developed by Paul Berg in 1972 by combining DNA from the monkey virus SV40 with the lambda virus (18). In conventional breeding methods, a single cross between two plants generate a set of around 15,000 to 25,000 genes together, in which there will be an immense genetic change. But, by the means of modern genetic engineering methods, only some particular genes will be transformed without altering the remaining genome and this benefit the breeders to access to an ample set of new genes, which can be transformed to local, high yielding varieties (19).

Through recombinant DNA technology, the genetic material of living organisms such as animals, plants or microorganisms will be altered and the resulting organism is said to be 'Genetically modified' (GM), 'Genetically engineered' or 'Transgenic' $(20,21)$. In this process, the gene will be integrated in the host genome and the protein encoded by the gene will express a specific character to that plant (22). With the advances in recombinant DNA technology, many transgenic crops expressing new characters were developed and commercially released to the market. These include pest resistant maize, cotton, canola (mainly for Bt or Bacillus thuringiensis), viral disease resistant papaya, potato and squash, herbicide glyphosate resistant cotton and soybean, etc $(23,24)$. The first genetically altered plant was tobacco that is produced in 1983 and approved in USA and France as herbicide tolerant and an economic crop resistant to the bromoxynil herbicide (25) (Table 1). In addition, the first commercially cultivated genetically modified whole food crop was tomato (called as FlavrSavr), which has long shelf life, developed by a Californian company, Calgene (25). Besides them, various transgenic crops were in pipeline and were not yet commercially released, which have the characteristics of phytoremediation, biofortification and production of plant based pharmaceuticals like rice with immense level of carotenoid for the production of vitamin A (e.g. Golden rice) and bananas containing vaccines (26).

Table 1. Timeline of events featuring the present era of GM crops

\begin{tabular}{ll}
\hline \multicolumn{1}{c}{ Year } & \multicolumn{1}{c}{ Achievements } \\
\hline 1946 & $\begin{array}{l}\text { Scientists discovered that DNA can be transferable } \\
\text { between species }\end{array}$ \\
\hline 1954 & $\begin{array}{l}\text { Discovery of DNA, conception of central dogma by } \\
\text { Watson and Crick }\end{array}$ \\
\hline 1973 & $\begin{array}{l}\text { First genetic recombination experiment was } \\
\text { conducted by Boyer and Cohen }\end{array}$ \\
\hline 1983 & $\begin{array}{l}\text { First GM plants (Tobacco, Petunia) were } \\
\text { successfully produced }\end{array}$ \\
\hline 1990 & $\begin{array}{l}\text { China becomes the first country to commercialize } \\
\text { GM crops }\end{array}$ \\
\hline 1994 & $\begin{array}{l}\text { First FDA approved GM crop for human } \\
\text { consumption (Flavr Savr Tomato: Calgene, USA) }\end{array}$ \\
\hline 1996 & $\begin{array}{l}\text { First genetically modified soybean was introduced } \\
\text { in the United States market }\end{array}$ \\
\hline 1996 & $\begin{array}{l}\text { Bt cotton was first approved for commercial use in } \\
\text { the United States }\end{array}$ \\
\hline 2002 & GM cotton was first approved in India \\
\hline 2002 & Transgenic mustard DMH - 11 was developed \\
\hline $2009-$ & $\begin{array}{l}\text { Bt brinjal was first commercialized on 14 } \\
\text { 2009, October } \\
\text { on 9 } \text { 9 }^{\text {th }} \text { February 2010 that it needs further testing }\end{array}$ \\
\hline 2010 & $\begin{array}{l}\text { Genetic } \\
\text { approved DMH - 11 for field studies }\end{array}$ \\
\hline & Committee \\
\hline 2018
\end{tabular}

Globally, genetic improvement of the major crops has been prominently facilitated by adopting several techniques like direct gene transfer or Agrobacterium tumefaciens mediated gene transfer depending upon the plant species (27-33). Even though, the recombinant DNA technology was emerged in 1983, the first genetically engineered crop was commercially released in mid 1990s and till date various transgenic crops have been developed having resistance to different biotic and abiotic stresses. Even though transgenic technology has 
Table 2. Various crops produced through tools of recent genetic engineering technology other than transgenesis

\begin{tabular}{|c|c|c|c|c|c|}
\hline Plant & $\begin{array}{l}\text { Technology } \\
\text { approached }\end{array}$ & Gene & $\begin{array}{l}\text { Kind of DNA } \\
\text { modification }\end{array}$ & Achieved trait & References \\
\hline Apple & \multirow{3}{*}{ Intragenesis } & HcrVf2 & Expression & Scab resistance & Joshi et al. 269 \\
\hline Alfalfa & & Comt & $\begin{array}{c}\text { Silencing Reduced } \\
\text { levels of }\end{array}$ & lignin & Weeks et al. 270 \\
\hline Potato & & StAs1, StAS2 & Silencing & $\begin{array}{l}\text { Limit acrylamide } \\
\text { in French Fries }\end{array}$ & Rommens et al. 271 \\
\hline Barley & \multirow{3}{*}{ Cisgenesis } & HvPAPhy_a & Over expression & $\begin{array}{l}\text { Improved grain } \\
\text { phytase activity }\end{array}$ & Holme et al. 272 \\
\hline Potato & & R-genes & Expression & $\begin{array}{l}\text { Late blight } \\
\text { resistance }\end{array}$ & Haverkort et al. 273 \\
\hline Durum wheat & & 1Dy10 & Expression & $\begin{array}{l}\text { Improvement in } \\
\text { baking quality }\end{array}$ & Gadaleta et al. 274 \\
\hline Arabidopsis thaliana & \multirow{5}{*}{$\begin{array}{l}\text { Zinc-finger } \\
\text { nucleases }\end{array}$} & RPP4 gene cluster & Large deletion & & Qi et al. 275 \\
\hline Glycine $\max$ & & $\begin{array}{l}\text { DCL1a/b, DCL4a/b, } \\
\text { RDR6a, HEN1a, } \\
\text { transgene }\end{array}$ & Knockout & & Curtin et al. 276 \\
\hline Arabidopsis thaliana & & ADH1, TT4 & Knockout & & Zhang et al. 277 \\
\hline Maize & & ZmIPK1 & $\begin{array}{l}\text { Homologous } \\
\text { recombination }\end{array}$ & $\begin{array}{c}\text { Herbicide } \\
\text { tolerant and } \\
\text { phytate reduced } \\
\text { maize }\end{array}$ & Shukla et al. 278 \\
\hline Rice & & OsQQR & $\begin{array}{l}\text { Homologous } \\
\text { recombination }\end{array}$ & Trait stacking & Cantos et al. 279 \\
\hline Hordeum vulgare & \multirow{4}{*}{ TALEN } & PAPhy_a & Knockout & & Wendt et al. 280 \\
\hline Glycine max & & FAD2-1A/B & Knockout & $\begin{array}{l}\text { Improved oil } \\
\text { quality }\end{array}$ & Haun et al. 281 \\
\hline Sugar cane & & COMT & $\begin{array}{l}\text { Non-homologous } \\
\text { end joining }\end{array}$ & $\begin{array}{c}\text { Enhanced cell } \\
\text { wall composition }\end{array}$ & Jung et al. 282 \\
\hline Triticum aestivum & & MLO & Knockout & $\begin{array}{c}\text { Resistance to } \\
\text { powdery mildew }\end{array}$ & Wang et al. 283 \\
\hline Zea mays & \multirow{2}{*}{ Meganuclease } & Intergenic sequence & Knockout & & Gao et al. 284 \\
\hline Zea mays & & MS26 & Knockout & Male sterility & Djukanovic et al. 285 \\
\hline $\begin{array}{l}\text { Tobacco; } \text { Arabidopsis } \\
\text { thaliana; sorghum; } \\
\text { Oryza sativa }\end{array}$ & \multirow{5}{*}{ CRISPR/Cas } & $\begin{array}{l}\text { OsSWEET14, } \\
\text { transgene }\end{array}$ & Knockout & & Jiang et al. 286 \\
\hline $\begin{array}{c}\text { Arabidopsis thaliana; } \\
\text { Nicotiana } \\
\text { benthamiana }\end{array}$ & & $\begin{array}{l}\text { AtPDS3, AtRACK1c, } \\
\text { NbPDS3 }\end{array}$ & Knockout & & Li et al. 287 \\
\hline Arabidopsis thaliana & & $\begin{array}{l}\text { TT4, GAI, BRI1, JAZ1, } \\
\text { CHLI, AP1, transgene }\end{array}$ & Knockout & & Feng et al. 288 \\
\hline $\begin{array}{c}\text { Oryza sativa; Triticum } \\
\text { aestivum }\end{array}$ & & $\begin{array}{c}\text { OsPDS, OsBADH2, } \\
\text { Os02g23823, } \\
\text { OsMPK2, TaMLO } \\
\end{array}$ & Knockout & & Shan et al. 289 \\
\hline Sweet orange & & PDS & Knockout & & Jia and Wang 290 \\
\hline Rice & \multirow{3}{*}{ CRISPR/Cas9 } & SBEIIb & $\begin{array}{c}\text { Non-homologous } \\
\text { end joining }\end{array}$ & $\begin{array}{c}\text { High amylose } \\
\text { content }\end{array}$ & Sun et al. 291 \\
\hline Wheat & & EDR1 & $\begin{array}{c}\text { Non-homologous } \\
\text { end joining }\end{array}$ & $\begin{array}{l}\text { Powdery mildew } \\
\text { resistance }\end{array}$ & Zhang et al. 292 \\
\hline Rice & & SBEIIb & $\begin{array}{c}\text { Non-homologous } \\
\text { end joining }\end{array}$ & $\begin{array}{c}\text { High amylose } \\
\text { content }\end{array}$ & Sun et al. 291 \\
\hline $\begin{array}{c}\text { Nicotiana } \\
\text { benthamiana }\end{array}$ & $\begin{array}{l}\text { TALE activator } \\
\text { (native TALE } \\
\text { activation domain, } \\
\text { VP16, GAL4) } \\
\end{array}$ & Transgene & $\begin{array}{l}\text { Control of gene } \\
\text { expression }\end{array}$ & & Geibler et al. 293 \\
\hline Arabidopsis thaliana & $\begin{array}{l}\text { TALE repressor } \\
\text { (SRDX) }\end{array}$ & RD29A, transgene & $\begin{array}{l}\text { Control of gene } \\
\text { expression }\end{array}$ & & Mahfouz et al. 294 \\
\hline
\end{tabular}

achieved substantial economic value relative to plant breeding, certain constraints are limiting its application in various commercially important crops that are recalcitrant to in vitro regeneration and genetic transformation which is to be addressed. In addition, the transgenic crops already developed were encountering disapproval and are not readily being accepted by the consumers due to food safety and environmental problems (34). The main worry of public in using transgenic crops is the incorporation of foreign DNA into the genome of the plants other than the plant's natural gene repository 
to attain certain characters. So, to meet this concern, two new transformation methods were developed as a substitute to regular transgenesis called as intragenesis and cisgenesis. In both of these techniques the plants should be transformed only with the genetic material isolated from the closely associated species capable of sexual hybridization. Traditional breeding methods have been conveniently developed for gene stacking, however only a few number of single loci could be basically stacked and is a totally long process, which is paving a way for scientists to search for new methods (35). In this regard, a set of new technologies jointly called as gene editing techniques are emerging as a prominent tools in current plant biotechnology as they promote fast editing of different genes by cisgenic, mutational or transgenic methods and setting genetic engineering methods easy and simple (36) (Table 2). The following are the newly developed gene editing technologies:

1. Engineered Meganucleases (EMNs): They are double stranded DNases also called as homing nucleases that aim broad recognition sites, which stimulates effective gene targeting by double stranded break induced homologous recombination, leads to reform breaks in the DNA double strands. The engineered meganucleases adopted from microorganisms are altered to create double stranded breaks, which acts as a standard platform to direct the enzymes and exactly allow them to cleave the DNA at target site in the process of recombination (37). They are utilized to produce herbicide resistance and insect tolerance in cotton (38) and male sterility in maize (39).

2. Zinc Finger Nucleases (ZFNs): They belong to group of artificial meganucleases DNA binding proteins that promotes specific genome editing by producing double strand breaks in the DNA at particular locations succeeded by genetic modification at the time of successive repair (40). They act as distinct genomic scissors and aids in fast integration or disruption into any loci and the mutations resulted are genetic and long-lasting. In various plants like maize they are utilized to generate herbicide resistance (41).

3. Oligonucleotide Mediated Mutagenesis (OMM): They are used to induce site specific mutations with the help of chemically integrated oligonucleotides similar to the target site (42). In rice (43) and maize (44), herbicide resistance was developed by oligonucleotide mediated mutagenesis.

\section{Transcription Activator-Like Effector}

Nucleases (TALENs): These are programmed nucleases consisting of DNA binding region of Xanthomonas derived effectors. They can bind to any specific DNA sequence, so when it is linked with a nuclease, DNA could be incised at particular sites. TALENs have the capability to develop important characters in an individual by the mode of target alteration of a gene family and aids in crop improvement and genome engineering (45). They are utilized to develop bacterial blight disease tolerance in rice (46), to enhance the soybean oil content (47) and to induce mutations in barley (48).

\section{Clustered Regularly Interspaced Short} Palindromic Repeats (CRISPR/Cas9): It is an alignment of programmable nucleases comprised of an individual single-guide RNA (sgRNA) and endonucleases derived from bacteria (Cas9). It is a method to develop breaks in double stranded DNA at particular genome sites, to alter, restore or combine new genes at those particular sites (49). After cleaving the DNA with site directed nucleases (SDNs) the cell could be driven to mutate solely with limited point alterations to the gene (SDN-1) or could add a template to create more deletions or insertions in the gene sequence (SDN-2) or add a template for inclusion of distinct gene as a whole, even from a far away species (SDN-3) (49). With the development of CRISPER/Cas9, the gene knockout process has become easy and it would seem to work in nearly all microbes. Bacterial blight disease resistance in rice (50) and drought resistance in maize (51) had been developed with CRISPER technology.

Over the past few years development of recombinant technology has been increased rapidly, where in 2017, the global area of genetically modified (GM) crops was increased by $3 \%$ i.e. 189.8 million hectares compared to 185.1 hectares in 2016, where 17 million farmers in 24 countries planted GM crops (52) (Fig. 1).

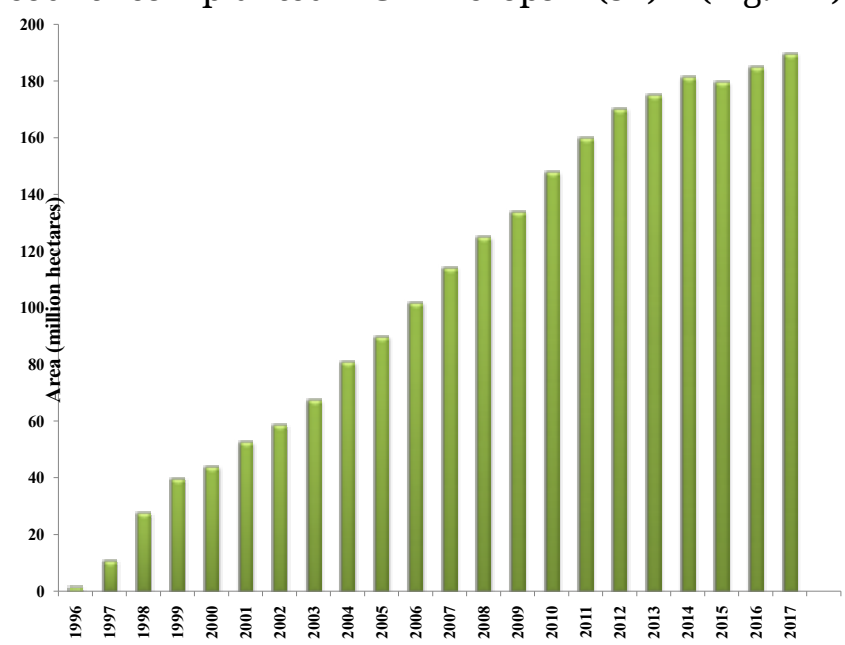

Fig. 1. Global area of genetically modified crops cultivated from 1996 to 2017

The ISAAA report mentioned that it is primarily due to greater profitability arriving from higher commodity prices, increased global and domestic market demand and available seed technologies. In the year 2017, 67 countries cultivated genetically modified crops, which include 24 countries in total that grew transgenic crops, including 19 developing and 5 industrial countries and in additional 43 non-planting countries that regulates the importation and use of biotech crops 
for food, feed and processing. Out of total GM crops cultivated, about $50 \%$ of the global area accounts for GM soybean varieties. The percentage of GM crops cultivated in the year 2017 in terms of global area were, $80 \%$ cotton, $77 \%$ soybean, $30 \%$ canola and $32 \%$ maize (52). The major producers and exporters of GM crops and their products are the United States of America, Argentina and Canada (53), where as in developing countries the largest producers are Argentina, Brazil, China and India (54). Among these countries, GM crops are prevalent in United States of America.

Among the developing countries the choice of GM crops varies, in which insect resistant cotton is the foremost commercially produced transgenic crop in Asian and African countries, whereas herbicide-resistant soybean followed by insectresistant corn is predominant in the Latin American continent. According to the ISAAA report (52), the current production of next generation biotech crops, like anthocyanin enhanced super sweet pineapple, apples and potatoes (which will not be damaged or spoiled quickly), insect resistant sugarcane, new soybean variety with altered oil content, high amylase and increased ear biomass maize varieties contributes to food producers and consumers. In the year 2017, India occupied fifth largest position in cultivating GM crops accounting to an area of 11.4 mha after US, Brazil, Argentina and Canada (52) (Fig. 2).

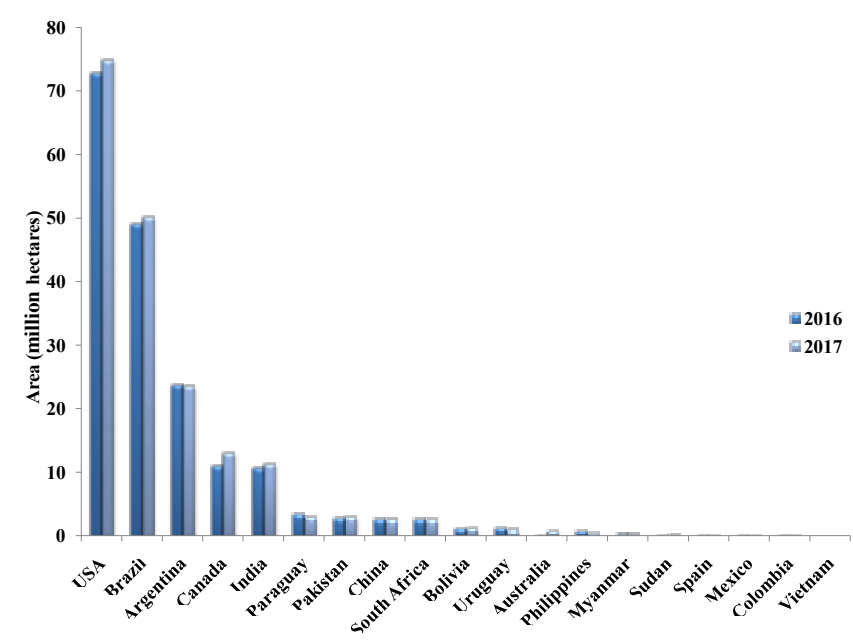

Fig. 2. Distribution of genetically modified crops among various countries in 2016 \& 2017

Based on the studies on GM crops related to global socio-economic and environmental impacts 1996-2016, conveyed by PG Economics (a UK-based consultancy firm specializing in GM crops), stated that in the last two decades, GM crops contributed to $\$ 186.1$ billion economic gains to about 17 million farmers, in which many of them are females and small holder farmers (55). According to the global report on food crises, in 2018 globally 113 million people in 53 countries are experiencing high levels of food insecurity in most severe food crisis (56). So, practice of modern agriculture through GM strategy can mitigate the problem of food crisis and reduce poverty in various countries.

\section{Genetic modification and its importance}

GMO (Genetically modified organisms) is described as "organisms (animals, plants or microorganisms) in which the genetic material is edited in a way that it will not be developed naturally by natural recombination or by mating (57). In this method, genes will be transferred within the same species or across the species or kingdoms and the endogenous genes can be altered, enhanced or knocked out. Food scarcity is the major problem around the world, due to the problems like increase in population, less crop yield due to biotic and abiotic stresses and unpredictable weather, which is severely affecting the farmers worldwide. The Food and Agriculture Organization of the UN (United Nations) has estimated that we need to grow $70 \%$ more food by 2050 globally to accommodate the demand of the 9 billion estimated population (58). In this perspective, generic modification or recombinant DNA technology is a potential tool to produce biotic and abiotic stress resistant and high yielding varieties.

\section{Methods of gene transfer}

For sustainable and commercial development of transgenic plants, effective genetic transformation methods must be developed for crop improvement. To get more productive transgenic plants, the major requirements are: a potent DNA delivery system, advantageous target tissues appropriate for effective regeneration, a highly reproducible and direct regeneration system to avoid somaclonal variations (59). Alternative to Agrobacterium mediated gene transfer, other direct transformation methods have been developed $(60,61)$ like microinjection (62), protoplast and intact cell electroporation (63-66), polyethyleneglycol-mediated (PEG) transfer (67) and gene gun technology (68). Even though, many methods are available Agrobacterium tumefaciensmediated gene transfer, direct DNA transfer into protoplasts by the means of osmotic or electric shock and high velocity bombardment of DNA coated microprojectiles called as the biolistic procedure are being used adequately. In these techniques, individual plant cells are targeted and are regenerated into whole GM plants using standardized tissue culture protocols.

\section{Agrobacterium tumefaciens-mediated genetic transformation}

Agrobacterium tumefaciens is a soil phytopathogen that naturally infects the plants and causes crown gall disease by transferring the T-DNA from bacterial cells into host cells through a bacterial type IV secretion system (T4SS). With the successful transformation efficiency in the host cells, A. tumefaciens has becomes the most suitable transformation tool to date. By the Agrobacterium mediated genetic transformation, any particular 
gene of interest can be used to change the oncogenes in the T-DNA region of various types of binary vectors. It has the distinct capability to transfer a particular DNA segment (T-DNA) of the tumor inducing (Ti) plasmid into the nucleus of infected cells where it is then stably integrated into the host genome and transcribed, causing the crown gall disease $(69,70)$. It plays an important role in the fields of plant genetic engineering and molecular biology. Until now $80 \%$ of transgenic plants were produced using Agrobacterium mediated plant transformation (71). At the beginning it was believed that only dicots and some monocots species can be transformed by this bacterium, but the present results has changed this aspect by demonstrating that many recalcitrant species, which are not included in its natural host range can be transformed $(72,73)$. Even though other methods are available, Agrobacterium mediated transformation method is mostly preferred over others due to its salient advantages like: reducing the transgene copy number, substantially causing minor problems with instability and transgene co-suppression $(74,75)$. Further it is a single-cell transformation system that does not produce mosaic plants, which are more frequent in direct transformation systems $(76,77)$.

\section{Protoplast transformation}

It involves the direct DNA transfer to the plant cells by using polyethylene glycol or electroporation. Once the DNA is transferred, it can be expressed or integrated stably into the genome (78). This method has the highest efficiency, where it has the possibility to attain more than $70 \%$ transformation rate. It has been successfully used to transfer genome-editing reagents in multiple crop plants like rice, wheat, flax, potato and sweet potato (79). Some important advantages of protoplast transformation are: (i) no need of binary vector, (ii) high percentage of transformation, (iii) can be employed in maximum number of plant species, (iv) transfer of multiple plasmids with high levels of co-transformation. Apart from these advantages, some disadvantages are also there like; limited plant species are susceptible to regenerate from protoplasts, labor intensive and time consuming (79).

\section{Particle bombardment (biolistics)}

Particle bombardment is another method of gene transfer, which is also termed as particle gun, particle bombardment, particle acceleration and micro projectile bombardment. Particle bombardment is primarily described as a method to produce transgenic plants mainly in recalcitrant cereals. It is a method of transferring foreign DNA into a living cell by the means of a glass micropipette (80). This includes over-expression of certain genes and is widely used for gene transfection in mammals. Advantages of this technique are: (i) target gene can be transferred directly into a single cell, (ii) marker gene is not required, (iii) the transformed cells can be easily identified by injecting the dye along with the DNA. It uses high velocity micro projectiles to transfer substances into cells and tissues and is the only transformation technique that can be applied to almost any cell or tissue type. This method is commonly applied for genetic transformation of many organisms and plants and is employed for the plants having low regeneration capacity which show low transformation efficiency with Agrobacterium gene transfer in the crops like corn, rice, wheat, chickpea, pigeon pea and sorghum. Advantages of this technique are: (i) it is a simple and convenient method, (ii) genome manipulation of sub-cellular organelles, (iii) accurate transfer of DNA or RNA. Apart from advantages, some disadvantages are also there, like: transformation efficiency may be lower than Agrobacterium mediated transformation, costly equipment is needed and chance of gene silencing due to multiple copy insertions $(81,82)$. But, it has been determined that in more events, these multiple copies are aligned as a single locus and segregate in a Mendilian pattern. Over the past two decades, micro-projectile bombardment has emerged as a stable and regular technique for the transgenic plants production by leaving Agrobacterium hostspecificity and difficulties of in vitro regeneration by tissue culture in many crops. With the help of biolistic approach, the complex pattern of transgene integration reported by the molecular studies can be avoided (60). This method has been used to obtain genetically engineered bean and Asparagus plants.

\section{Various other methods of transformation}

There is a need to develop more efficient and cost effective methods of plant transformation. Few of these methods are in planta, pollen and chloroplast mediated transformation. In planta transformation is a direct method without undergoing in vitro tissue culture work (83) and produces more number of plants with in a less time and with minimum chemical requirements (84). The two important methods of in planta transformation are vacuum infiltration and floral dip and both were promisingly been applied in vegetables, oil seeds, cereals and various other crops (85). Coming to the chloroplast transformation method, it has several advantages like multiple gene transfer in one transformation event, enhanced level of gene expression and with no gene silencing and pleiotropic effects. With the help of tobacco chloroplast genome, more than fourty genes have been firmly integrated and expressed to confer essential characters or expressed maximum levels of biopharmaceuticals and vaccine antigens (86). This method of transformation has been successful in several main crops like soybean, cotton $(87,88)$ and carrot (87). In addition to the above two methods, pollen transformation is also a potent method to transfer 
various foreign genes. Pollen transformation, succeeded by stigma pollination with transformed pollen grains and consequent choosing of genetically transformed plants and seeds is a fast and simple alternative method to produce transgenic plants by avoiding in vitro culture (88). Similar to other transformation methods, Agrobacterium tumefaciens could be applied as vector or the DNA could be directly transferred to the specific region and is capable of producing genetically transformed plants in less time. In case of Petunia hybrida, transgenic plants are produced by pollinating pollen grains next to vacuum infiltration with Agrobacterium tumefaciens (89). To produce transgenic maize plants, ultrasonication was applied to transfer plasmid DNA into maize pollen grains, which were later utilized for pollination of flowers (90). In case of Brassica juncea, sonication facilitated addition of aroAM1 gene adopting glyphosate as a selectable promoter was applied successfully (91).

\section{Achievements of transgenic technology}

Modern biotechnological techniques have rapidly expanded the horizons of plant breeding and crop improvement. In this process, development of different plant transformation techniques to produce various biotic and abiotic resistant crops to address several problems in agriculture led to the study of structure and function of desired genes. In the initial stages, single gene of interest was transferred into plants, but now-a-days with the help of developed advanced procedures, multiple genes against one metabolic pathway were successfully integrated (92). The major ways adopted to produce improved transgenic plants are communicated below.

\section{Development of biotic and abiotic stress resistant crops}

A major loss in the crop yield is due to various biotic and abiotic factors that affect the plant growth which limit their geographical distribution. To address these problems, genetic transformation is an important mechanism to impart disease resistance and enhance crop yield that leads to a new revolution in crop improvement. The below sections will discuss about some of the transgenic crops developed against biotic and abiotic stresses.

\section{Herbicide tolerance (HT)}

Weed control is a regular problem in agricultural fields, where they not only compete with crops for nutrients, water, sunlight and area but also block irrigation and drainage systems; dispersal of weed seeds into crop harvests and decrease the crop quality and yield (93). Herbicides are used as a primary means to control weeds in current agriculture, even though their wrong application directed the development of herbicide tolerant weeds (94). Conventional agricultural systems can only use 'selective' herbicides that do not harm the crop but are not effective in removing all types of weeds but during this period some of the weeds become tolerant to few normally utilized herbicides (95). Several crops have been genetically modified which are resistant to nonselective herbicides. Agrobacterium-mediated transformation and particle bombardment methods are the most widely used methods in the production of herbicide-resistant crops (96). In addition, other biotechnological methods like mutagenesis and in vitro cell culture can also be used to develop herbicide tolerance (97).

The transgenic crops developed consist of genes that enable them to degrade the active ingredient in a herbicide and rendering it harmless. Farmers can there by easily control weeds during the entire growing season and have more flexibility in choosing spraying times and these herbicide resistant crops also facilitate low or no tillage cultural practices, which are considered to be more sustainable (98). Another advantage is that farmers can manage weeds without switching to some of the environmental susceptible herbicides. The global herbicides utilization in HT crops has increased during the time period 1998 to 2013, where increase in rate $(\mathrm{kg} / \mathrm{ha})$ of active ingredient in HT soybean was 64 $\%$ relative to $19 \%$ in traditional soybean variety (99).

Herbicide resistance has been developed in many crop species, such as oilseed rape, maize, soybeans, sugar beet, fodder beet, cotton, rice and coffee (100-105). The first herbicide-tolerant GM plants commercially grown were glyphosatetolerant soybeans $(106,107)$. The gene that imparts herbicide tolerance is derived from the soil bacterium Agrobacterium tumefaciens that encodes an EPSPS (5-enolpyruvylshikimate 3phosphate synthase) is not affected by glyphosate. Presently, 36 different weed varieties tolerant to EPSPS inhibitor (major transgenic herbicide), glyphosate and about 159 varieties tolerant to ALSsuppressing herbicides have been developed (108). Today, at least 36 weed species have evolved resistance to glyphosate, EPSPS inhibitor (the main herbicide in transgenic HR crops), and at least 159 to ALS-inhibiting herbicides (the main group of herbicides in non-transgenic HR crops) (109).

In the USA and Canada, Glufosinate and bromoxynil tolerant varieties of oilseed rape have been successfully developed (110). In the year 2002, herbicide tolerant GM crops like $15 \%$ of maize, $59 \%$ of upland cotton and $81 \%$ of soybean $(111,112)$ were cultivated in the USA. In addition, $66 \%$ of canadian oilseed rape and $95 \%$ of Argentine soybean herbicide tolerant GM plants were also produced during the same period (113). From 1996 to 2017, most of the planting area of biotech crops was occupied by herbicide tolerant crops. In the single year 2017, herbicide tolerant crops inhabited 88.7 million hectares or $47 \%$ of the 189.8 million hectares of the total biotech crops planted globally (52). Based on the studies 
carried out by the council for agricultural science and technology, it was assessed that the environment gains by the adoption of HT crops. For example, in the US, no-till soybean acreage has increased by $35 \%$ from the period of introduction of herbicide tolerant soybean. The same situation was observed in Argentina, where $98 \%$ of soybean fields were planted with herbicide tolerance varieties. Since the early 21 years of commercialization (1996-2016), profits from HT crops were estimated at US\$ 89.02 billion, global biotech crop value of US\$ 186.1 billion with $47.8 \%$ and in the single year 2016 at US\$ 8.44 billion or $46.4 \%$ of global value of US\$ 18.2 billion (52).

\section{Insect pest resistance}

Development of genetically engineered pest resistant crops reduced the usage of broadspectrum insecticides, which provide a safer, more biologically sustainable way of managing insect pests. Various pests attack plants and cause immense loss and low product quality that leads to major global food security and every year $25 \%$ of food crops were destroyed globally (114). Experience has shown that crop yields can be enhanced or increased with decreased spraying of pesticides. For example, European corn borer (ECB) (Ostrinia nubilalis), annually generates a loss up to 2 billion dollars in the USA alone (115). Bacillus thuringiensis is a soil-borne gram positive bacterium discovered in diseased silkworms by Ishiwatari in 1901 to control various pests (116). It produces a protein called as $B t$ toxin, which is produced in an inactive, crystalline protein form that is toxic to various herbivorous insects and have high insecticidal activity at very low concentrations. Whenever insects consume this, the protein is converted to its active toxic form (delta endotoxin) and destroys the gut of the insect and kills it (117), because this particular protein is active form in alkaline condition inside the gut of the insect, where as in humans this protein will be digested inside the stomach due to its acidic nature. Bt preparations are commonly used in organic agriculture to control insects, as they occur naturally and safe for humans. More than 100 different variations of $B t$ toxin have been identified in diverse strains of Bacillus thuringiensis and they have different target insect specificity. For example, toxins classified under Cry1a group target Lepidoptera (butterflies), and toxins in the Cry3 group are effective against beetles (118-121).

In China, cultivation of cotton bollworm resistant cotton varieties decreased the application of chemical pesticides that not only reduces the adverse effects on the environment but also minimizes the negative effect of pesticides on farmer's health $(122,123)$. Due to the reasons of improved health benefits and high yield by low pesticide use, commercialization of Bt cotton has been increased globally, mainly in Asian countries like India (124) and China (125). In India, transgenic rice varieties resistant to Scirpophagain certulas walker (yellow stem borer) were developed (126) which eradicated yield loss caused by Lepidopteran insects, that accounts to Asia's 2 to $10 \%$ annual rice yield of 523 million tons (127). Among the different GM insect resistant varieties developed, transgenic rice variety exhibited high resistance to yellow stem borer (128). In 2017 ( $22^{\text {nd }}$ year of GM crops commercialization), 24 countries cultivated 189.8 million hectares of GM crops compared to 185.1 million hectares in 2016 with a raise of $3 \%$ or 4.7 million hectares (129).

Till date, more than 700 Cry gene sequences associated with crystal proteins have been identified (130) and these proteins were reported to eradicate Coleoptera, Lepidoptera, Hymenoptera and Diptera pests in the fields (131). In addition to these, alternative anti-insect genes like plant agglutinins and plant protease inhibitors, non- $B t$ genes from bacteria (Pseudomonas entomophila, Serratia entomophila and Morganella morganii) and other genes from fungi [Beauveria bassiana, Metarhizium anisopliae (countering locusts or beetles) and $B$. brongniartii] were also identified (132). But, most of the insect pests are not affected and regulated properly by these genes. Hence, more research is needed to analyze most potent insect resistant genes.

\section{Disease resistance}

Continuous efforts are being made for the development of alternative approaches in plant disease management to reduce the application of chemical fertilizers. Bacterial, viral and fungal diseases are absolutely adjustable for natural adaption and effect the plant growth. Amongst the various approaches, resistance breeding has produced authorized information and had been used extremely. In normal environment, complex systems of defenses in plants operate at various zones to get protection from many diseases (133). Now-a-days, interpretation of these defensive pathways has emerged as a specific area of research in the field of plant molecular biology and will be a developing concept to study the multiple interactions among initial defenses and distinct disease resistance (134). Plants developed through breeding techniques (' $R$ ' genes or Resistance genes), may not exert disease resistance to some pathogens due to their developed pest resistance and may finally result in on set of diseases (135). The traditional conventional breeding methods alone are not enough to control the pathogens because of the in adequacy of suitable crop variations and in spite of such breeding techniques identification of resistant genes has been one of the main targets from many years $(136,137)$. So, the present conditions demand the identification of variations towards the biotic stress by the recognition of genes across the species.

From over the past two decades, 
significant work has been made in plant disease management by the means of genetic engineering. Besides this, many molecular approaches have been evolved to resolve various plant-pathogen systems and correlated disease-resistance genes. With the advanced plant transformation techniques, promising genes can be transferred to produce disease resistant plants and outcome has been achieved by producing various disease resistant transgenic crops. One such gene is the Bs2 gene (Bacterial spot resistance gene) from pepper, which has been successfully used to accomplish resistance against agriculturally serious bacterial spot disease in tomatoes (138).

Two main bacterial blight resistant genes, Xa21 (Xanthomonas Oryzae PV. Oryzae Resistance 21) and Xa13 (Xanthomonas Oryzae PV. Oryzae Resistance 13) were incorporated into the famous basmati rice variety Pusa Basmati 1 and in the year 2007 it was released into the market as 'Improved Pusa Basmati 1' variety (139). Sundaram et al. (140) incorporated three bacterial blight resistant genes Xa21, Xa13 and Xa5 (Xanthomonas Oryzae PV. Oryzae Resistance 5) in the best Samba Mahsuri rice variety and named it as 'Improved Samba Mahsuri', which is a high yielding and bacterial blight resistant variety (141). Few examples of other disease resistance genes are oxalate degrading enzyme, OXDC (oxalate decarboxylase), expressed in tomato, lathyrus, soybean and tobacco had shown high resistance to the pathogen Sclerotinia sclerotiorum that uses oxalic acid at the time of host settlement $(142,143)$. By using the RNA interference strategy (RNAi), which is a main regulatory mechanism for gene expression and anti-viral protection in eukaryotes, the defense mechanism can be improved against the pathogens in various crops (144-146). Virus infection is also one of the major problems in many crops that result in significant yield loss. In the process of management the viral coat protein has been used to bring resistance against viruses and this is one of the best methods used in genetic engineering. Some of the virus resistant plants brought to the market are PYV tolerant varieties of potato (potato $\mathrm{Y}$ virus) or PLRV (Potato Leaf Roll Virus) (147). Virus resistance was also attained by the use of sense and antisense RNA by governing the replication associated protein (AC1) of African Cassava Mosaic or the $C 1$ gene from the Gemini virus and resistance can also be shown by expressing the defective viral Movement Protein (MP) (148). One of the new ways to develop virus resistant plants is Post Transcriptional Gene Silencing (PTGS), which produces broad range of virus resistant plants. Example of PTGS method generated resistance is against Gemini viruses in plants (149). By the method of RNA silencing, transgenic virus resistant papaya was produced against Papaya ring spot POTYVIRUS (150).
Transgenes can be expressed in whole plants to promote disease resistance by the constitutive expression of AMPs (Antimicrobial peptides) under CaMV35S (Cauliflower mosaic virus $35 \mathrm{~S}$ promoter) or ubiquitin promoters to increase crop yield. By this way, endo-1, 3-beta-dglucanase gene from potato was expressed in tea plant to develop blister blight resistance in tea (151). Likewise, Хoo bacterial blight resistant transgenic rice was developed by the overexpression of OSPR10a gene (152). In another study, constitutive expression of Tfgd2 (Trigonella foenum-graecum defensin 2) - RsAFP2 (Raphanus sativus antifungal protein 2) fusion gene under CaMV35S promoter in transgenic tobacco plants displayed improved insect and disease resistance against Phytophthora parasitica var. nicotianae, Rhizoctonia solani pathogens and Spodoptera litura pest (153). Expression of SniOLP (S. nigrum osmotin-like protein) and RsAFP2 (Raphanus sativus antifungal protein 2) genes in transgenic peanut plants under separate CaMV35S promoters exhibited improved resistance to late leaf spot disease caused by Phaeoisariopsis personata (154). Plants developed to attain eminent levels of salicylic acid also displayed improved disease resistance (155). In transgenic plants, different antibacterial proteins from various sources other than plants also exhibited resistance to bacterial diseases (156).

\section{Abiotic Stress tolerance}

For three decades, the molecular biology approaches have extended the chances of directly modifying the genomes of higher plants to alter their metabolism to improve the growth and yield under unfavorable environmental conditions to furnish the human requirements (157-160). Since the $19^{\text {th }}$ century, the carbon dioxide concentration in the atmosphere has been constantly increasing and currently reached to $400 \mathrm{ppm}$ at some observed locations (161) that is increasing the global warming which has become a major issue in the last few years. Even though it is crucial to accomplish raising carbon dioxide concentrations with extreme weather conditions like drought, heavy rain, or low and high temperatures, these are attained with increased frequency (162). Agriculture was entrenched by acclimatizing plants to grow in particular climatic conditions as the yield relies upon the climatic conditions and usually reduces at the time of extreme weather (163). Further, advancement of saline or drought conditions due to different human activities are decreasing the available cultivated land and yield, but there is demand of requirement of higher yields (164).Worldwide, more than $50 \%$ of the crop yield was being affected due to abiotic stress (165). Previous reports states that, globally about 800 million hectares of lands are saline, which covers about $6 \%$ of the total area and in addition to that salinity has damaged about $20 \%$ of cultivable land (166). The practice of irrigation 
made certain land available for cultivation and according to current estimation over $20 \%$ of the global cultivable land is irrigated which contributes $40 \%$ of food and feed (167), but $50 \%$ of land was under salinity (168). Different surveys presumes that there is a threat of losing $30 \%$ of cultivable land in a period of 25 years and about $50 \%$ by 2050 (169) and according to the recent reports, presently $70 \%$ of the global fresh water is utilized by agriculture (167). Hence, productive usage of water resources is important for future agricultural practices.

Even though, traditional plant breeding methods afford marginal support, genetic engineering techniques provide rapid and efficient strategy methods for managing stress related problems especially in improving plant stress tolerance. In this approach, one of the best classical ways of enhancing stress tolerance is to evaluate and distinguish the resistant genes and transfer them to higher plants. To avoid the stress conditions, plants have adapted various methods to overcome the stress challenges by choosing either a system which makes them to sustain from the adverse effects or developing certain growth habits. At transcriptional and translational stages, hundreds of genes and their products react to the abiotic stresses (170). Depending on the function, genes correlated with abiotic stress are categorized into three groups: Functional proteins, signaling factors and transcriptional factors. Relative to signaling factors which include proteins engaged in signal transduction regulation, functional proteins involve genes that regulates abscisic acid (ABA) synthesis, antioxidant protectants, reactive oxygen species scavenging proteins, chaperons, LEA proteins and heat shock proteins (HSPs), which are engaged in giving protection. Transcriptional factors (DREB1/CBF, AP2/ERF, DREB2, NAC, MYB/MYC, basic leucineZipper proteins and Zinc-finger proteins) are connected with integrity of ion and cell homeostasis. At the molecular stage, abiotic stress tolerance could be developed by gene transfer by modifying the aggregation of osmoprotectants, chaperones synthesis, superoxide radical scavenging mechanisms, compartmentation or exclusion of ions through competent symporter and transporter systems (171-175). Among different stress factors, drought and salinity are considered as the most serious problems decreasing the agricultural production on an overall range. The global environmental conditions are expected to continue leading to increased both salt and drought stresses.

\section{Drought}

For more than 20 years, various scientists have performed immense research on the structural, biochemical, physiological, molecular regulation and on morphological traits to disclose the methods of drought responses of plants. The plant reaction to the drought stress is a multiple process comprising different genes and signaling pathways. Genes engaged in these reactions could be arranged into two major classes: single function genes and regulatory genes based on their biological function (176). The single function genes encode enzymes associated with the accumulation of osmolytes, proteins and enzymes scavenging oxygen radicals (ROS), proteins associated with the uptake and transport of water and ions (ion transporters, channels), and proteins involved in lipid biosynthesis (177). Even though, many genes have been recognized that they can impart drought tolerance in plants only few drought tolerant crops have been developed, because the progress has been restricted to produce such tolerant crops for field conditions or commercialization. The first drought tolerant transgenic plant is MON 87460, a maize variety developed in the year 2009 by Monsanto company and was first sown in 2013 in the country US, which increased the yield 5.5 fold from 50,000 ha in 2013 to 2,75,000 ha in 2014 (178). This variety expresses cold shock protein B (CSPB) from Bacillus subtilis to provide drought tolerance. This protein in MON 87460 variety manages normal cellular functions under drought stress conditions by retaining RNA stability and translation (179). Further, the over-expression of CSPB was noted to impart stress tolerance in Arabidopsis and rice (180). Drought tolerant transgenic crops like rice, maize, canola and cotton were develloped in fields in the years 2009 to mid-2011s (181). Most of the new experiments were performed in rice, which is a wonderful model variety and is one of the most important crops worldwide. Stress responsive NAC1 (SNAC1) an NAC-type transcription factor, is particularly inferred in guard cells under drought stress conditions. Over-expression of SNAC1 in rice developed an enhanced drought tolerance under serious drought conditions at reproductive stage in the field, where $22-34 \%$ higher seed setting was observed (182). Similarly, over-expression of AVP1 in tomato, rice and Arabidopsis improved plant efficiency under drought stress and salt conditions $(183,184)$.

\section{Salinity}

Another major abiotic stress is salinity stress and in India about 6.73 million ha is affected with salinity (185). This has encouraged scientists to develop various techniques to produce high yielding transgenic plants. Various studies stated that the salt tolerance is firmly associated with the capacity of maintaining ion homeostasis under salinity. It was reported that salt tolerant plants are capable of tolerating other stresses besides drought, freezing, heat and chilling (186). Using modern technology, already, transgenic plants were developed in many crops for abiotic stress tolerance which includes tomato (187), tobacco (188), rice (189), Arabidopsis thaliana and Brassica napus (190) and cotton, maize, oilseed rape and wheat $(191,192)$. These GM plants retained high 
photosynthetic ability with maximum levels of photosynthesis-associated enzymes. Currently, a gene encoding aquaporin (NtAQP1) was recognized in tobacco (Nicotiana tabacum) and exhibited to give protection against salinity stress in transgenic tomato (Solanum lycopersicum) (182). NtAQP1 plays a key role in preventing shoot or root hydraulic failure by increasing the water use efficiency to promote salt tolerance. Based on previous literature, it was reported that glutathione (GSH) plays a key role in antioxidant defense system in plants and rise in glutathione synthesis including GSH/GSSG ratio has been observed to be associated with stress tolerance (193). The glyoxalase pathway comprising glyoxalase I (gly I) and glyoxalase II (gly II) enzymes are required for glutathione based detoxification of methyl glyoxal (MG). GM tobacco plants over-expressing glyI and glyII enzymes were developed and they were reported to have high metal and salinity tolerance than non GM crops $(194,195)$. In the recent findings, they observed that over-expression of rice gly II gene in rice exhibited resistance to toxic levels of methylglyoxal and $\mathrm{NaCl}$ compared to the non GM plants (196). Asif et al. (197) reported that transgenic plants incorporated with AtNHX (Arabidopsis thaliana $\mathrm{Na}(+) / \mathrm{H}(+)$ exchanger 1 ) gene are highly resistant to high salt concentrations and water loss than the wild type plants and the accumulation of proline and salt was higher in the leaves of transgenic plants compared to the wild type plants. Transgenic groundnut with enhanced drought and salt tolerance was developed by overexpression of AtNHX1 (Arabidopsis thaliana $\mathrm{Na}(+)$ / $\mathrm{H}(+)$ exchanger 1) gene (197) Ying-Hui Guo et al. (198) reported that GhZFP1 (Gossypium hirsutum zinc finger protein 1), a new CCCH-type zinc finger protein isolated from salt induced cotton, improves salt tolerance and fungal disease resistance in transgenic tobacco by combining with GZIRD21A (GhZFP1 interacting and responsive to dehydration protein 21A) and GZIPR5 (GhZFP1 interacting and pathogenesisrelated protein 5). These zinc fingers are a super family involved in various factors of plant growth and development.

\section{Waterlogging}

The major threats to food security are floods and droughts (199), where the agriculture fields are usually flooded by severe or huge rainfall for a period of time. Around the world, during the period 2006 to 2016, two-thirds loss of crops and destruction are due to floods, with a loss of billions of dollars (199). Depending on the height of the produced water column, flooding could be categorized as waterlogging, when it is depthless and masks the root only, or over flow, where water fully masks the aerial parts of the plant tissues (200). The two kinds of floods disturb the oxygen movement from the air to the plant tissues
(201), generating a common situation called as hypoxia $\left(<21 \% \mathrm{O}_{2}\right)(200)$.

Currently, flooding conditions like waterlogging, submergence, anoxia and hypoxia were examined widely in various plants, primarily in Arabidopsis and rice, to analyze molecular components that are capable of playing role in resistance to flooding. The incorporation of ethanolic fermentation pathway is studied to be a crucial element of reactions, which are obtained in rice and in other plants contrary to flood stress $(202,203)$. Two different methods are been tried to recognize the inhibiting factors in response to waterlogging. First one is the individual candidate genes under-expression, e.g. sense and anti-sense constitutes for ethanol synthesis and second is the transcription factors over-expression (204). It was expected that the two methods are advantageous in converting the extended term modification reaction to less oxygen stress.

Conversion of pyruvate to ethanol called as ethanolic fermentation is comparably simple method, which involves two enzymes, pyruvate decarboxylase (PDC) and alcohol dehydrogenase (ADH). Cloned PDC and ADH availability will increase the interest of molecular biology scientists to use them for transgenic experiments. In relation to this, the primary outcome of transgenic rice consisting of cotton ADH cDNA proposed that PDC over-expression will not exhibit high resistance to submergence. In a study (205), Taipei-309 transplanted with pdc1 associated to a constitutive $35 \mathrm{~S}$ promoter has shown 3 fold increased activities of PDC and ethanol production when exhibited anoxia related to non transformed control plants. In contrary to this, another study (206) examined Taipei-309 transformed with pdc1 where the two transgenic lines had two fold high PDC activities and showed $43 \%$ high percentage of ethanol production, but the durability of seed lines which were anoxia exposed was less compared to non-transformed plants. Transgenic cotton plants transformed with ADH cDNA directed by the 35S promoter exhibited ten to thirty fold enhanced $\mathrm{ADH}$ activity and an appreciable increase in the ethanol fermentation rate (207).

\section{Cold stress}

Low temperature has enormous effect on the geographical distribution and survival of the plants. Relying upon the period and severity of stress it influences a variety of cellular metabolisms in the plant cycle. Through various studies it was determined that the primary location of freezing damage in plants is the membrane systems (208, 209). Different subtropical and tropical region species are damaged or killed by non-frost low temperatures and show different freezing injuries like necrosis, chlorosis or growth delay. Relative to this, frost resistant varieties are capable to cultivate at cold temperatures, but numerous forms of damage to 
the membrane will occur as a result of freeze generated cellular dehydration inclusive of lamellar-to-hexagonal-II phase transitions, expansion-generated-lysis and fracture jump lesions (210). Adapting living cells to freezing temperatures is an activity of altering the membrane lipid content by enhanced unsaturated fatty acids.

The use of genetic engineering in various crops by the incorporation of genes encoding cold resistant metabolites and proteins are found be a substitute to overcome the low-temperature abiotic stress. In this condition, helicases are known to play a key role in cold sensitivity in plants. Plants have more number of DEAD-box RNA helicase genes relative to other living things (142). Among the helicases, LOS4 encoded by the Arabidopsis osmotically responsive genes, is known to be vital for attaining tolerance to freezing and chilling in plants (143). Further, Arabidopsis nucleoporin AtNUP160, SAR1 (suppressor of auxin resistance1) also regulates RNA export and is important for developing freezing and chilling tolerance (147). A group of genes that encodes cold regulated (COR) proteins, were utilized by various researchers to recognize Arabidopsis transcription factors family called as generally dehydration responsive element-binding factors (DREB) (DREB1B, DREB1C and DREB1A) or C-repeat binding factors (CBF) (CBF1, CBF2 and CBF3) (211). The over-expression of CBF1/DREB1b and CBF3/DREB1a increases the cold resistance by promoting COR (cold regulated genes) genes and it further leads to various biochemical alterations like aggregation of proline and sugar (212-215). Transgenic tomato (Solanum lycopersicum) transformed with CBF1 cDNA within the regulation of a CaMV35S promoter exhibited enhanced resistance to salt, drought and chilling but still showed adverse effects like decreased fruit set, less number of seeds per fruit and dwarf nature (216). In a study (217), genetically engineered tomato with ring zinc finger protein (RDCPt) derived from hot pepper (Capsicum annum) developed enhanced resistance to cold in transgenic plants relative to non-transgenic plants. Over-expression of OsMYB3R-2 in transgenic Arabidopsis showed enhanced resistance to freezing while exposed to $-80^{\circ} \mathrm{C}$ for $10 \mathrm{~h}$ (218).

Genetically transformed tobacco plants which are over-expressed with glycerol-3phosphate acyltransferase (GPAT) chloroplast gene from Cucurbita maxima (squash) and Arabidopsis thaliana exhibited high unsaturated fatty acids number and parallel reduction in chilling susceptibility. A cold sensitive nucleic acid binding protein, a zincfinger consisting glycine rich RNA binding protein derived from Arabidopsis represented as atRZ-1a is upregulated by cold stress and genetic studies helps in attaining freezing resistance (219). The Arabidopsis nucleoporin AtNUP160 suppressor of auxin resistance1 (SAR1) also regulates RNA export, and is important for freezing resistance and chilling (220). Pramanik and Imai (221) stated that, TPP (trehalose-6-phosphate phosphatase) genes expressed in rice are induced by cold. The overexpression of TPP genes and TPS (trehalose-6phosphate synthase) increased the aggregation of trehalose and resistance to cold stress in transgenic tobacco and rice (222-225).

\section{Nutritional quality improvement}

By genetic modification techniques, the nutritional quality and food content of crops can be improved and among the different crops developed cassava and rice are one of the major areas of interest for GM foods. Malnutrition is the major sustaining problem in developing countries, where most of the people depend on a sole crop like rice as major source of their diet (226). Rice is the main crop for nearly half of the people but it is not a good source of vitamin A (227). Globally, every year around 250,000 to 500,000 malnourished children are suffering from blindness due to vitamin A inadequacy, in which $50 \%$ of them die annually (228). Ingo Potrykus and Peter Beyer in collaboration with International Rice Research Institute (IRRI) developed a new rice variety, containing $\beta$-carotene in its grains, which is a precursor to vitamin A (229). It has taken 25 years to develop and test the rice varieties having adequate amounts of $\beta$-carotene, which could eradicate the mortality and morbidity due to vitamin A deficiency (227). This "Golden rice" variety was inferred substantially to reduce blindness caused due to vitamin A deficiency (226). Vitamin A deficiency due to poor intake of diet and food scarcity results in development of major health problems estimated to cause 1.9 to 2.8 million deaths every year, and among them severely affected are women and children below 5 y (227). Further research is going on to develop new iron rich golden rice variety (226). Cassava is another crop, which is altered to enhance the nutritional content to provide healthy diet in developing countries. This starchy food is consumed by most of the people in tropical Africa, where $40 \%$ of the calories come from it (230). Developed GM cassava variety is pest tolerant and consists of vitamin A, proteins and high mineral content, which can avoid childhood blindness, anemia, infections caused due to impaired immune systems (230). Thus, it is more reliable and staple food for the people of tropical Africa. In addition to cassava, other food crops like GM maize were developed by inserting a cordapA gene (Corynebacterium glutamicum dap A promoter) from a soil bacteria Corynobacterium glutamicum to produce increased lysine (LY038) content. Increased production and aggregation of free lysine in the genetically modified corn kernel led to the increase in body weight, feed conversion and body yields of experimental poultry in comparison to animals fed with lysine augmented 
diets and higher than those fed with common maize diets (231). In the experiment conducted on rats, lysine enriched GM maize variety derived by the insertion of a gene from potato is also safe as common maize varieties (232). Soybean variety M703 developed for enhanced protein levels contains more digestible amino acids like methionine, lysine, threonine and valine and was experimentally proven in cockerels that it has major level of metabolizable energy than traditional soybean food (233). Narrow-leafed lupin (Lupinus angustifolius) which is expressing methionine-rich sunflower albumin was reported to increase methionine content twice compared to the others. If genetically modified high-methionine lupine varieties are provided to the broilers diet, supplementation of additional methionine consisting of $25 \%$ lupin food could be decreased by $0.6 \mathrm{~g} / \mathrm{kg}(234)$.

\section{Genetic modifications of plants to develop commercial products}

\section{Biodegradable plastics}

Naturally plants produce different polymers, like cellulose or starch and are been utilized for the plastic synthesis. Furthermore, new plastics such as polyhydroxyalkanoates (PHAs) were too produced from the plants. One of the promising advantages of transgenic crops is the production of biodegradable plastics (235) particularly PHB (polyhydroxybutyrate) and PHV (PolyhydroxyValerate). Plants may be treated as renewable, adaptable and comparably sustainable sources of plantibodies or edible vaccines $(236,237)$, fatty acids and new oils $(238,239)$ and biodegradable plastics. Harmony among the enzyme information and the genes conferring to PHA production in bacteria and plant metabolic engineering approaches would be essential for the improvement of crops that synthesize biodegradable plastics. Transgenic varieties of cotton, corn, and mustard have been genetically engineered to produce first plant based synthesized plastic compounds in the world (240). For the production of PHAs on large scale at low cost relative to artificial plastics has emerged from the presentation of PHA aggregation in transgenic Arabidopsis plants expressing bacterial PHA biosynthetic genes.

Developed biodegradable plastics can be degraded completely in composters or in sewage treatment plants using naturally occurring microorganisms. They don't leave any toxic, distinct or apparent waste after degradation. Such type of plastics, duly industrialized, may supply a green alternative to conventional petrochemical plastics like polyethylene, polypropylene and polystyrene and act as a source of crop based plastics. These can be synthesized from a renewable source like plants fossil material, which are biodegradable. Recently, Michigan state university scientists presented a new approach to produce economical biodegradable plastics by using an ancient microorganism under sunlight. They conducted an experiment on cyanobacteria that use sunlight to produce sugar naturally and genetically designed them to uniformly flow the sugar into the surrounding salt water medium. The treated biomass consists of nearly $30 \%$ of bioplastic, which is four times more than the other identical experimental systems and the production rate was around 20 times faster (241). This reduces the plastic production from the fossil fuels and minimizes the negative effect of plastic on the environment (241). Researchers are focusing on genetic modification of cyanobacteria, which is also called as blue green algae to produce PHA (polyhydroxyalkanoates), which are promising raw materials for bioplastic production. Scientists from the RIKEN center for sustainable resource science also worked on blue green algae, developed a cyanobacterium strain, which yields triple amount of enhanced bioplastic polyhydroxybutyrate (PHB) than the normal strain (242). The species of cyanobacterium known as Synechocystis begin to generate PHB when nutrients like nitrogen become deficient. This metabolic adoption aids the survival of cyanobacteria under low resource conditions, but under the normal conditions the organisms will not generate adequate amounts of PHB for economical applications. To increase the production of PHB, scientists have engineered a Synechocystis strain that has enhanced expression levels of Rre37, a regulatory protein which is involved in sugar metabolism at the time of nitrogen scarcity. Genetic and metabolic analysis of Rre37 showed that, it promotes the conversion of glycogen, a sugar storage molecule into PHB (242). They further stated that, a novel regulator in Rre37 was found that activates bioplastic production in cyanobacteria. In addition to this, the same scientists earlier recognized one more protein i.e. SigE, which is involved in bioplastic production.

\section{Biopharmaceuticals and Edible vaccines}

Plants have the potential to produce peptides and biopharmaceutical proteins as they can be transformed efficiently and serve as a cheap economic source of protein. To produce recombinant pharmaceuticals in plants two different transformation strategies were commonly applied (243-247). In the first method, transgenic plants are produced by Agrobacteriummediated transformation, particle bombardment or other regular transformation techniques and the second technique is to infect non transgenic plants with recombinant viruses that express transgenes at the time of replication in the host (248-250). Tobacco was the first plant to be genetically engineered and has the advantage of being used as a plant biopharmaceutical since the methods for gene transfer and expression are well established in this plant. One more reason is it can 
be cultivated several times per year and produces large amount of biomass compared to other plants (251). In a pioneering study (252), for the first time transferred a chimeric gene of nopaline synthase and human growth hormone into sunflower and tobacco plants by using the Ti plasmid. Soon after, mouse monoclonal antibody was synthesized and assembled into tobacco leaf sections (247). Similar to bioreactors, plants can produce high amounts of recombinant proteins, which are not contaminated with any microorganisms of humans or animals and can be stored without chilling at low cost. Using this strategy, many recombinant proteins have been secreted in plants and the protein based pharmaceuticals production has switched from mammalian, fungal and bacterial cultures to plant cell cultures and plants (253-255). Now, different commercialized reagents and enzymes produced from plants were available. For example, type I collagen, that can self-assemble into fine homogenous fibrils, were synthesized in plants (256) similarly bovine trypsin was synthesized in maize and TrypZean (Sigma-Aldrich) has been in the market since 2002. One more example is human lysozyme and lactoferrin, which were synthesized from rice $(257,258)$. The process of producing plant based biopharmaceuticals from transgenic tobacco or carrot cells has been developed by Protalix, an Israeli company (259, 260). From Food and Drug Administration (FDA) of the United States, Protalix and its partner Pfizer acquired permission for taliglucerase alfa production for Gaucher's disease. Next, for the first time, transgenic plant derived biopharmaceutical, hirudin, is now being commercially produced in Canada (261).

Edible vaccines act as an alternative to traditional vaccines and can overcome the restrictions of conventional vaccines. Production of vaccines in plants was first undertaken in the year 1989 (247). The idea of using transgenic plants as platforms to produce and deliver subunit vaccines was brought by Dr. Arntzen and his colleagues $(262,263)$ and confirmed that this approach may overcome the constraints in conventional vaccine production (264). Plants that have been selected to use as bioreactors are potato, tobacco, rice and corn. The first subunit vaccine was produced in tobacco plants by expressing surface protein antigen of streptococcus mutants (264). They also began the production of hepatitis B and heat liable toxin B subunit in potato plants and potato tubers (264). Since, plant based vaccines are easy to handle, cost effective, easy production on large scale and also avoid difficulty in storage, this process may be a reasonable substitute for vaccine production (265267). Till date, many transgenic plants have been used to synthesize four different types of vaccines viz. viral vaccines, bacterial vaccines, immune contraceptive vaccines and parasite vaccines (268).

\section{Conclusion}

As the global population is expected to reach 9 billion by 2050, adoption of new crop improvement technologies is crucial to face the upcoming problems in future. In this aspect, among the various new technologies developed, GM technology offers significant profits to farmers as they can reduce the present challenges in commercial agriculture and the current market forecast them as one of the world's rapidly flourishing creative sectors, benefiting not only farmers, customers and also contribute major economies in different countries. Currently, the new transgenic technologies like RNA interference-mediated gene silencing technology, gene targeting for enhanced efficiency and zincfinger nuclease gene targeting technology are concentrating on finding novel genes and developing new approaches for plant biology research. Although, genetically modified crops are not only the universal solution to combat the problems of malnutrition and hunger, but also GM crops can act as an essential part of food safety programme. Thus, through new advances in gene integration techniques, in the development of stress resistance and biofortification, GM crops are expected to add efficiency and profit for commercial agriculture in future.

\section{Acknowledgements}

Sincere thanks are extended to financial support from Science and Engineering Research Board (SERB) - Young Scientist Scheme (SB/YS/LS-83/2014 to Dr. K. Vasavi Rama). The authors also acknowledge the support of Department of Biotechnology, GITAM Institute of Technology, GITAM (Deemed to be University), Visakhapatnam in successful completion of this study.

\section{Authors' contributions}

All authors contributed equally in the preparation as well as revision of the manuscript and approved the final version.

\section{Conflict of interest}

The authors declare that they have no competing interests.

\section{References}

1. Southgate EM, Davey MR, Power JB, Merchant R. Factors affecting the genetic engineering of plants by microprojectile bombardment. Biotechnology Advances 1995;13:31-57. https://doi.org/10.1016/0734-9750(95)02008-X

2. Wollenweber, Porter B, Lubberstedt J, Thomas. Need for multidisciplinary research towards a second green revolution - Commentary. Current opinion in plant biology. 2005;8:337-41. https://doi.org/10.1016/j.pbi.2005.03.001 
3. Raymond Park J, McFarlane I, Hartley Phipps R, Ceddia G. The role of transgenic crops in sustainable development.Plant Biotechnology Journal.2011;9:2 21.https://doi.org/10.1111/j.1467-7652.2010.00565.x

4. Ahmad P, Sarwat M, Sharma S. Reactive oxygen species, antioxidants and signaling in plants. Journal of Plant Biology. https://doi.org/10.1007/BF03030694

5. Ahmad P, Nabi G, Jeleel CA, Umar S. Free radical production, oxidative damage and antioxidant defense mechanisms in plants under abiotic stress. In: Ahmad P, Umar S, editors. Oxidative stress: role of antioxidants in plants. New Delhi: Studium Press Pvt. Ltd; 2011.p.19-53.

6. Ahmad P, Prasad MNV. Abiotic Stress Responses in Plants: Metabolism, Productivity and Sustainability. New York, NY Springer Science Business Media. 2012a; LLC 10.1007/978-14614-0634-1. https://doi.org/10.1007/978-1-4614-0634-1

7. Vinod Kumar B, Raja TK, Wani MR, Sheikh SA, Lone MA Gowher Nabi, et al. Transgenic plants as green factories for vaccine production. 2013;12(43):6147-58 https://doi.org/10.5897/AJB2012.2925

8. Kant S, Bi YM, Rothstein SJ. Understanding plant response to nitrogen limitation for the improvement of crop nitrogen use efficiency. Journal of Experimental Botany. 2011;62:1499-1509. https://doi.org/10.1093/jxb/erq297

9. Vianna GR, Aragao FJL, Rech EL. A minimal DNA cassette as a vector for genetic transformation of soybean (Glycine max) Genet Mol Res. 2011;10:382-90. https://doi.org/10.4238/vol10-1gmr1058

10. Yoshida T, Kimura E, Koike S, Nojima J, Futai E, Sasagawa $\mathrm{N}$, et al. Transgenic rice expressing amyloid Bpeptide for oral immunization. International journal of biological sciences.2011;7(3):301-07. https://doi.org/10.7150/ijbs.7.301

11. Sharma M, Sood B. A banana or a syringe: journey to edible vaccines. World Journal of Microbiology and Biotechnology. 2011;27(3):471 77.https://doi.org/10.1007/s11274-010-0481-9

12. Twyman RM, Schillberg S, Fischer R. The production of vaccines and therapeutic antibodies in plants, In: Wang A Ma S, editors. Molecular farming in plants: Recent advances and future prospects. Springer Science+Business Media, New York;2012.p. 145-59. https://doi.org/10.1007/978-94-007-2217-07

13. Wall RJ. New gene transfer methods. Theriogenology. 2002;57:189-201. $\quad$ https://doi.org/10.1016/S0093691X(01)00666-5

14. Wheeler MB, Walters EM. Transgenic technology and applications in swine. Theriogenology. 2001;56:1345-69. https://doi.org/10.1016/S0093-691X(01)00635-5

15. Wheeler MB, Walters EM, Clark SG. Transgenic animals in biomedicine and agriculture: outlook for the future. Animal Reproduction Science. 2003;79:265-89. https://doi.org/10.1016/S0378-4320(03)00168-4

16. Naqvi S, Farre G, Sanahuja G, Capell T, Zhu CF, Christou P. When more is better: multigene engineering in plants. Trends in Plant Science. 2010;15:48-56. https://doi.org/10.1016/j.tplants.2009.09.010

17. Zaynab M, Pan D, Fatima M. Transcriptomic approach to address low germination rat in Cyclobalnopsis gilva seeds. South African Journal of Botany. 2018;119:286-94. https://doi.org/10.1016/j.sajb.2018.09.024

18. Jackson DA, Symons RH, PaulBerg. Biochemical method for inserting new genetic information into DNA of simian virus 40: Circular SV40 DNA molecules containing lambda phage genes and the galactose operon of Escherichia coli. Proceedings of the National Academy of Sciences. 1972;69:2904-09. https://doi.org/10.1073/pnas.69.10.2904

19. Zilberman D, Holland TG, Trilnick I. Agricultural GMOsWhat We Know and Where Scientists $\begin{array}{lll}\text { Disagree } & \text { Sustainability. 2018;10(5):1514 }\end{array}$ https://doi.org/10.3390/su10051514

20. Babaoglu M, Davey MR, Power JB. Genetic engineering of grain legumes: key transformation events. Agri Biotech Net. 2000;2:1-12.
21. Zhang C, Wohlhueter R, Zhang H. Genetically modified foods: A critical review of their promise and problems. 2016;5(3):116-23. https://doi.org/10.1016/j.fshw.2016.04.002

22. Key S, Ma JK, Drake PM. Genetically modified plants and human health. Journal of the Royal Society of Medicine. 2008;101(6):290-98. https://doi.org/10.1258/irsm.2008.070372

23. FAO. FAOSTAT. Food and Agriculture Organization of the United Nations; 2012. Available from: http://faostat.fao.org/ default.aspx

24. Clive J. Global status of commercialized Biotech/GM crops. ISAAA Briefs 43. Ithaca: International Service for the Acquisition of Agri-biotech Applications; 2011.

25. Martineau B. First fruit. The creation of the flavr tomato and the Birth of Biotech foods. MC Graw-Hill Press. 2001;269.

26. Shahid AA, Bano S, Khalid S, Samiullah TR, Bajwa KS, Ali MA. Biosafety assessment of transgenic $B t$ cotton on model animals, Journal of Advancements in Life SciencesInternational Quarterly Journal of Biological Sciences. 2016;3(3):97-108.

27. Altpeter F, Varshney A, Abderhalden O, Douchkov D, Sautter C, Kimlehn J, et al. Stable expression of a defenserelated gene in wheat epidermis under transcriptional control of a novel promoter confers pathogen resistance. Plant Molecular Biology. 2005;52:271-83. https://doi.org/10.1007/s11103-004-7564-7

28. Datta K, Baisakh N, Oliva N, Torrizo L, Abrigo E, Tan J, et al. Bioengineered 'golden' indica rice cultivars with $\beta$ carotene metabolism in the endosperm with hygromycin and mannose selection systems. Plant Biotechnology Journal. 2003;1(2):81-90. $\quad$ https://doi.org/10.1046/j.14677652.2003.00015.x

29. Datta SK. In: Biotechnology in Agriculture and Forestry. In: Pua EC, Davey MR, editors. Transgenic crops IV Vol. 5. Springer-Verlag, Berlin Heidelberg; 2007.p.1-31.

30. Mackill D. Rice improvement in the genomics Era. In: Datta SK, editors, Howarth, New York; 2006.p.1-14.

31. Sahrawat AK, Becker D. Lutticke S, Lorz H. Genetic improvement of wheat via alien gene transfer, an assessment. Plant Science. 2003;165(5):1147-68. https://doi.org/10.1016/S0168-9452(03)00323-6

32. Sharma M, Charak KS, Ramanaiah TV. Agricultural biotechnology research in India: Status and policies. Current Science. 2003;84:297-302. https://doi.org/10.1029/2003EO320008

33. Vasil IK. The story of transgenic cereals: The challenge, the debate, and the solution-A historical perspective. In vitro cellular and developmental biology plant. 2005;41:577-83. https://doi.org/10.1079/IVP2005654

34. Kamthan, Chaudhuri A, Kamthan A, Datta M, Asis. Genetically modified (GM) crops: milestones and new advances in crop improvement. Theoretical and Applied Genetics. 2016;129. 10.1007/s00122-016-2747-6 https://doi.org/10.1007/s00122-016-2747-6

35. Que Q, Chilton MD, de Fontes CM, He C, Nuccio M, Zhu T, et al. Trait stacking in transgenic crops: challenges and $\begin{array}{lll}\text { opportunities. GM Crops. 2010;1(4):220-29. } & \text {. }\end{array}$ https://doi.org/10.4161/gmcr.1.4.13439

36. Samanta MK, Dey A, Gayen S. CRISPR/Cas9: An advanced tool for editing plant genomes. Transgenic Research 2016;25:561-73. https://doi.org/10.1007/s11248-016-9953-5

37. Molina R, Montoya G, Prieto J. Meganucleases and their biomedical applications, eLS. 2011; https://doi.org/10.1002/9780470015902.a0023179

38. D Halluin K, Vanderstraeten C, Van Hulle J, Rosolowska J, Brande IVD, Pennewaert A, et al. Targeted molecular trait stacking in cotton through targeted double strand break induction. Plant biotechnology journal. 2013;11:933-41. https://doi.org/10.1111/pbi.12085

39. Cigan AM, Singh M, Benn G, Feigenbutz L, Kumar M, Cho MJ, et al. Targeted mutagenesis of a conserved antherexpressed P450 gene confers male sterility in monocots. 
Plant Biotechnology Journal. 2017;15(3):379-89. https://doi.org/10.1111/pbi.12633

40. Urnov FD, Rebar EJ, Holmes MC, Steve Zhang H, Gregory PD. Genome editing with engineered zinc finger nucleases. Nature reviews of genetics. 2010;11:636-46. https://doi.org/10.1038/nrg2842

41. Shukla VK, Doyon Y, Miller JC, DeKelver RC, Moehle EA, Worden SE, et al. Precise genome modification in the crop species Zea mays using zinc-finger nucleases. Nature. 2009;459:437-41. https://doi.org/10.1038/nature07992

42. Wolt JD, Wang K, Yang BT. The Regulatory Status of Genome-edited Crops. Plant Biotechnology Journal.2016;14:510-18. https://doi.org/10.1111/pbi.12444

43. Okuzaki A, Toriyama K. Chimeric/RNA/DNA Oligonucleotide directed gene targeting in rice. Plant cell reproduction. https://doi.org/10.1007/s00299-003-0698-2

44. Zhu T, Peterson DJ, Tagliani L, Clair GS, Baszczynski LC, Ben Bowen. Targeted manipulation of maize genes in vivo using chimeric RNA/DNA oligonucleotides Proceedings of the National Academy of Sciences USA. 1999;96:8768-73. https://doi.org/10.1073/pnas.96.15.8768

45. Pennisi E. The tale of the TALEs. Science. 2012;338:1408-11. https://doi.org/10.1126/science.338.6113.1408

46. Li T, Liu B, Spalding MH, Weeks DP, Bing Yang. Highefficiency TALEN-based gene editing produces diseaseresistant rice. Nature Biotechnology. 2012;30:390-92. https://doi.org/10.1038/nbt.2199

47. Huan W, Coffman A, Clasen BM, Demorest ZL, Anita Lowy, Erin Ray, et al. Improved soybean oil quality by targeted mutagenesis of the fatty acid desaturase 2 gene family Plant Biotechnology Journal. 2014;12:934-40. https://doi.org/ 10.1111/pbi.12201

48. Wendt T, Holm PB, Starker CG, Christian M, Voytas DF, Brinch-Pedersen $\mathrm{H}$, et al. 'TAL effector nucleases induce mutations at a pre-selected location in the genome of primary barley transformants. Plant Molecular Biology. 2013;83:279-85. https://doi.org/10.1007/s11103-013-0078-4

49. Kuzma J, Kokotovich A, Kuzhabekova A. Attitudes towards governance of gene editing. Asian Biotechnology and Development Review. 2016;18:69-92.

50. Jiang W, Zhou H, Bi H, Michael Fromm, Bing Yang, Weeks DP. Demonstration of CRISPR/Cas9/sgRNA-mediated targeted gene modification in Arabidopsis, tobacco, sorghum and rice. Nucleic Acids Research. 2013;41:e188. https://doi.org/10.1093/nar/gkt780

51. Shi Jinrui, Gao Huirong, Wang Hongyu, Lafitte HR, Archibald RL, Meizhu Yang, et al. ARGOS8 variants generated by CRISPR-Cas9 improve maize grain yield under field drought stress conditions. Plant biotechnology journal. 2016;15. https://doi.org/10.1111/pbi.12603

52. Biotech crop adoption leads to greater sustainability and socioeconomic opportunities for global farmers and citizens [Internet]. PG Economics \& ISAAA[updated 2018 June 26]. Available from: http:// www.pgeconomics.co.uk

53. James C. Global status of commercialized biotech and gm crops: 2010. International Service for the acquisition of agribiotech applications. Ithaca, NY: ISAA;2010.

54. James C. Global status of commercialized Biotech/GM crops. ISAAA Breifs 51; 2015.

55. Brookes G, Barfoot P. GM Crops: Global Socio-economic and Environmental Impacts: 1996-2016. UK: PG Economics Ltd. 2018.

56. State of food Security and Nutrition in the World (formerly SOFI). Global Report on Food Crises; 2018. Canberra: The Department; 2018. Available from: http://www.fsinplatform.org@FSIN News

57. World Health Organization. World health statistics 2016 : monitoring health for the SDGs, sustainable development goals. World Health Organization. 2016; https://apps.who.int/iris/handle/10665/206498

58. Tim S, Craig H, Janet R, Brian L, Richard W, Robert W, et al. Creating a sustainable food future. A menu of solutions to sustainably feed more than 9 billion people by 2050. World resources report 2013-14. interim findings: World Resources Institute; 2014.

59. Hansen G, Wright MS. Recent advances in the transformation of plants. Trends in Plant Science. 1999;4:226-31. https://doi.org/10.1016/S1360-1385(99)01412$\underline{0}$

60. Shillito R, Saul M, Paszkowski J, Muller M, Potrykus I. High efficiency direct transfer to plants. Biotechnology. 1985;3:1099-1103. https://doi.org/10.1038/nbt1285-1099

61. Potrykus I. Gene transfer to plants: Assessment of published approaches and results. Annu. Rev. Plant Physiol. Plant Molecular Biology. 1991;42:205-25. https://doi.org/10.1146/annurev.pp.42.060191.001225

62. De la Pena A, Lorz H, Schell J. Transgenic rye plants obtained by injecting DNA into young floral tillers. Nature. 1987;325:274-76. https://doi.org/10.1038/325274a0

63. Fromm M, Taylor L, Walbot V. Expression of genes transferred into monocotyledonous and dicotyledonous plant cells by electroporation. Proceedings of the National Academy of Sciences USA. 1985;82:5824-28. https://doi.org/10.1073/pnas.82.17.5824

64. Fromm M, Taylor L, Walbot V. Stable transformation of maize after gene transfer by electroporation. Nature. 1986;319:791-93. https://doi.org/10.1038/319791a0

65. Lorz H, Baker B, Schell J. Gene transfer to cereal cells mediated by protoplast transformation. Molecular General Genetics. https://doi.org/10.1007/BF00330256

66. Arencibia A, Molina P, de la Riva G, Selman-Housein G. Production of transgenic sugarcane (Saccharum officinarum L.) plants by intact cell electroporation. Plant Cell $\quad$ Reports. 1995;14:305-3|09. https://doi.org/10.1007/BF00232033

67. Uchimiya H, Fushimi T, Hashimoto H, Harada H, Syono K, Sugawara Y. Expression of a foreign gene in callus derived from DNA-treated protoplasts of rice (Oryza sativa L.). Mol Gen Genet. 1986;204:204-07. https://doi.org/10.1007/BF00425499

68. Sanford J. The biolistic process. Trends in Biotechnology. 1988;6:299-302. https://doi.org/10.1016/0167-7799(88)90023$\underline{6}$

69. Nester EW, Gordon MP, Amasino RM, Yanofsky MF. Crown gall: a molecular and physiological analysis. Annual Review of Plant Physiology. 1984;35:387-413. https://doi.org/10.1146/annurev.pp.35.060184.002131

70. Binns AN, Thomashow MF. Cell biology of Agrobacterium infection and transformation of plants. Annual Review of Microbiology. 1988;42:575-606 https://doi.org/10.1146/annurev.mi.42.100188.003043

71. Gutierrez-Mora A, Santacruz-Ruvalcaba F, Cabrera-Ponce JL, Rodriguez-Garay B. Genetic improvement of plants in vitro. 2003; e-Gnosis 1:Art 4.

72. Bundock PA, den Dulk-Ras A, Beijerbergen A, Hooykaas PJJ. Trans-kingdom T-DNA transfer from Agrobacterium tumefaciens to Saccharomyces cerevisiae. EMBO Journal. 1995;14:3206-14. 2075.1995.tb07323.x

https://doi.org/10.1002/j.1460-

73. Chan MT, Chang HH, Ho SL, Tong WF, Yu SM. Plant Molecular Biology. 1993;22:491-506. https://doi.org/10.1007/ $\underline{\mathrm{BF} 00015978}$

74. Koncz C, Nemeth K, Redei GP, Schell J. Homology recognition during T-DNA integration into the plant genome. In Homologous Recombination and Gone Silencing in Plants In: Paszkowski, J, editors. Dordrecht: Kluwer Academic Publishers; 1994, p. 167-89. https://doi.org/10.1007/978-94-011-1094-5 9

75. Hansen G, Shillito RD, Chilton MD. Tstrand integration in maize protoplasts after codelivery of a T-DNA substrate and virulence genes. Proceedings of the National Academy of Sciences USA. 1997;94:11726-30. https://doi.org/10.1073/pnas.94.21.11726 
76. Enriquez-Obregon GA, Vazquez-Padron RI, PrietoSamsonov DL, Perez M, Selman-Housein G. Genetic transformation of sugarcane by Agrobacterium tumefaciens using antioxidants compounds. Biotecnologia Aplicada. 1997;14:169-74.

77. Enriquez-Obregon GA, Vazquez-padron RI, Prietosansonov DL, de la Riva GA, Selman Housein G. Herbicide resistant sugarcane (Saccharum officinarum L.) plants by Agrobacterium mediated transformation. Planta. 1998;206:20-27. https://doi.org/10.1007/s004250050369

78. Mathur J, Koncz C. PEG-mediated protoplast transformation with naked DNA. Methods in Molecular Biology. 1998;82:267-76. https://doi.org/10.1385/0-89603391-0:267

79. Baltes NJ, Gil-Humanes J, Voytas DF. Chapter One - Genome Engineering and Agriculture: Opportunities and Challenges. Progress in Molecular Biology and Translational Science. 2017;149:1-26. https://doi.org/10.1016/bs.pmbts.2017.03.011

80. Yao Q, Cong L, Chang JL, Li KX, Yang GX, He GY. Low copy number gene transfer and stable expression in a commercial wheat cultivar via particle bombardment. Journal of Experimental Botany. 2006;57(14):3737-46. https://doi.org/10.1093/jxb/erl145

81. Dai S, Zheng P, Marmey P, Zhang S, Tian W, Chen S, et al. Comparative analysis of transgenic rice plants obtained by Agrobacterium-mediated transformation and particle bombardment. Molecular Breeding. 2001;7:25-33. https://doi.org/10.1023/A:1009687511633

82. Behrooz Darbani, Safar Farajnia, Mahmoud Toorchi, Saeed Zakerbostanabad, Shahin Noeparvar, Neal Stewart C Jr. DNA-Delivery Methods to Produce Transgenic Plants. Biotechnology. https://doi.org/10.3923/biotech.2008.385.402

83. Feldmann KA, Marks MD. Agrobacterium mediated transformation of germinating seeds of Arabidopsis thaliana: a non-tissue culture approach. Molecular and General https://doi.org/10.1007/BF00330414

84. Bent A. Arabidopsis in Planta Transformation. Uses, Mechanisms and Prospects for Transformation of other Species. Plant Physiology. 2000;124:1540-47. https://doi.org/ 10.1104/pp.124.4.1540

85. Jan SA, Shinwari ZK, Shah SH, Shahzad A, Zia M, Ahmad N. In-planta transformation: Recent advances. Romanian Biotechnological Letters. 2016;21:11085-91.

86. Daniell H, Kumar S, Dufourmantel N. Breakthrough in chloroplast genetic engineering of agronomically important crops. Trends in Biotechnology. 2005;23(5):23845. https://doi.org/10.1016/j.tibtech.2005.03.008

87. Kumar S, Dhingra A, Daniell H. Plastid expressed betaine aldehyde dehydrogenase gene in carrot cultured cells, roots and leaves confers enhanced salt tolerance. Plant Physiology. https://doi.org/10.1104/pp.104.045187

88. Dufourmantel N, Pelissier B, Garcon F, Peltier G, Ferullo JM, Tissot G. Generation of fertile transplastomic soybean. Plant Molecular Biology. 2004;55:479-89.

89. Tjokrukusumo D, Heinrich T, Wylie S, Potter R, Mc Comb J. Vacuum infiltration of Petunia hybrida pollen with Agrobacterium tumefaciens to achieve plant transformation. Plant Cell Reports. 2000;19:792-97. https://doi.org/10.1007/s002990050009

90. Wang JX, Sun Y, Cui G, Hu J. Transgenic maize plants obtained by pollen-mediated transformation. Acta Botanica Sinica. 2001;43:275-79.

91. Wang J, Li Y, Liang C. Recovery of transgenic plants by pollen mediated transformation in Brassica juncea. Transgenic Research. https://doi.org/10.1007/s11248-007-9115-x

92. Karri Vasavi rama, Bharadwaja Kirti. Tandem combination of Trigonella foenum-graecum defensin (Tfgd2) and Raphanus sativus antifungal protein (RsAFP2) generates a more potent antifungal protein. Functional \& integrative genomics. 2013;13 :435-43. https://doi.org/10.1007/s10142 013-0334-3

93. Bleasdale JKA, Salter Peter John. The Complete Know and Grow Vegetables. Oxford University Press. Oxford University Press; 1991.

94. Beckie HJ, Harker KN, Hall LM, Warwick SI, Legere A Sikkema PH, et al. A decade of herbicide-resistant crops in Canada. Canadian Journal of Plant Science. 2006;86(4):1243-64. https://doi.org/10.4141/P05-193

95. Green JM. Current state of herbicides in herbicide-resistant crops. Pest Management Science. 2014; 70(9):1351-57. https://doi.org/10.1002/ps.3727

96. Tsaftaris A. The development of herbicide tolerant crops. Field Crops Research. 1996;45: 115-23. https://doi.org/10.1016/0378-4290(95)00064-X

97. Mulwa, Richard Mwanza, Mwanza LM. Biotechnology approaches to developing herbicide tolerance/selectivity in crops. African Journal of Biotechnology. 2006;5: 396-404.

98. Sankula S, Marmon G, Blumenthal E. Biotechnology derived crops planted in 2004. Impacts on US agriculture, NCFAP (National Center for Food and Agricultural Policy), Washington. 2005. $101 \mathrm{p}$.

99. Brookes G, Barfoot P. Environmental impacts of genetically modified (GM) crop use 1996-2013: Impacts on pesticide use and carbon emissions. GM Crops Food. 2015; 6(2):10333. https://doi.org/10.1080/21645698.2015.1025193

100. Kim HA, Utomo SD, Kwon SY, Min SR, Kim JS, Yoo HS, et al. The development of herbicide-resistant maize: stable Agrobacterium-mediated transformation of maize using explants of type II embryogenic calli. Plant Biotechnology Reports. 2009;3:277-83. https://doi.org/10.1007/s11816-0090099-2

101. Green JM, Castle LA. Transitioning from single to multiple herbicide-resistant crops. In: Nandula VK, editor Glyphosate Resistance in Crops and Weeds: History, Development, and Management. John Wiley \& Sons, Inc.; Hoboken, NJ, USA;2010. p.67-92. https://doi.org/10.1002/9780470634394.ch4

102. Latif A, Rao AQ, Khan MA, Shahid L, Bajwa KS, Ashraf MA, et al. Herbicide-resistant cotton (Gossypium hirsutum) plants: an alternative way of manual weed removal. BMC Research Notes. 2015;8:453. https://doi.org/10.1186/s13104 015-1397-0

103. Tingzhang $\mathrm{Hu}$. A glutathione s-transferase confers herbicide tolerance in rice. Crop Breeding and Applied Biotechnology. 2014;14:76-81. https://doi.org/10.1590/198470332014v14n2a14

104. Brookes G, Barfoot P. GM crops: global socio-economic and environmental impacts 1996-2013. 2015 http://www.pgeconomics.co.uk/page/38/ Accessed $28 \mathrm{Sept}$ 2015.

105. Reddy KN, Nandula. Herbicide resistant crops: History, development and current technologies Indian Journal of Agronomy. 2012;57(1):1-7.

106. Padgette SR, Kolacz KH, Delannay X, Re DB, Lavallee BJ, Tinius CN, et al. Crop Science. 1995;35:1451-61. https://doi.org/10.2135/cropsci1995.0011183X003500050032 $\underline{x}$

107. Bonny S. Genetically Modified Glyphosate-Tolerant Soybean in the USA: Adoption Factors, Impacts and $\begin{array}{llll}\text { Prospect- } & \text { A } & \text { Review. }\end{array}$ https://doi.org/10.1051/agro:2007044

108. Heap I. The International Survey of Herbicide Resistant Weeds. Online. Internet. Wednesday, December 18, 2019. Available www.weedscience.org

109. Huang J, Hu R, Pray C, Qiao F, Rozelle S. Agricultural economics. 2003;29:55-67. https://doi.org/10.1111/j.15740862.2003.tb00147.x

110. De Block MD, Botterman J, Vandewiele M, Dockx J, Thoen C, Gossele V, et al. Engineering herbicide resistance in plants by expression of a detoxifying enzyme. The European Molecular Biology Organization Journal. 1987;6:2513-18. https://doi.org/10.1002/j.1460-2075.1987.tb02537.x 
111. Benbrook CM. Impacts of genetically engineered crops on pesticide use in the United States: the first eight years. Bio Tech Info Net. Technical Paper Number 6. 2003; http://www.biotech-info.net/technicalpaper6.html

112. Forster VA. Crop Biotechnology. 2002;829:17-22. https://doi.org/10.1021/bk-2002-0829.ch003

113. Srivastava N, Gupta VK, Pati R, Gaur RK. Genetically by Modified Crops: An Overview. Biotechnology. 2011;10(2):136-48. https://doi.org/10.3923/biotech.2011.136.148

114. Arun Khurana. Plant Protection, Quarantine and Storage in India. Employment news [Internet]. 2017;26. Available from: https://www.e-employmentnews.co.in

115. Hyde J, Martin MA, Preckel PV, Edwards CR. The economics of $B t$ cotton: valuing protection from the European corn borer. Applied Economic Perspectives and Policy. 1999;21(2):442-54. https://doi.org/10.2307/1349890

116. Bravo A, Gomez I, Porta H,Garcia-Gomez BI, Almazan CR, Pardo L, et al. Evolution of Bacillus thuringiensisCry toxins insecticidal activity. Microbial Biotechnology. 2013;6(1):1726. https://doi.org/10.1111/j.1751-7915.2012.00342.x

117. Bravo A, Gill SS, Soberon M. Mode of action of Bacillus thuringiensisCry and Cyt toxins and their potential for insect control. Toxicon. 2007;49:423-35. https://doi.org/10.1016/j.toxicon.2006.11.022

118. Hofte H, Whiteley HR. Insecticidal Crystal Proteins of Bacillus thuringiensis. Microbiology Reviews. 1989;53:24255.

119. Bradley D, Harkey MA, Kim MK, Biever KD, Bauer LS. The insectidal CryIB crystal protein of Bacillus thuringiensis ssp. thuringiensis has dual specificity to Coleopteran and Lepidopteran larvae. Journal of Invertebrate Pathology. 1995;65:162-73. https://doi.org/10.1006/jipa.1995.1024

120. Genissel A, Leple JC, Millet N, Augustin S, Jouanin L, Pilate G. High tolerance against Chrysomela tremulae of transgenic poplar plants expressing a synthetic cry3Aa gene from Bacillusthuringiensis ssp tenebrionis. Molecular Breeding. https://doi.org/10.1023/A:1022453220496

2003;11:103-10

121. Bravo A, Likitvivatanavong S, Gill SS, Soberon M. Bacillus thuringiensis: a story of a successful bio insecticide. Insect Biochemistry and Molecular Biology. 2011;41:423-31. https://doi.org/10.1016/j.ibmb.2011.02.006

122. Pray CE, Huang J, Ma D, Qiao F. Impact of $B t$ cotton in China. World Development. 2001; 29:813-25. https://doi.org/ 10.1016/S0305-750X(01)00010-9

123. Lu Y, Wu K, Jiang Y, Guo Y, Desneux N. Wide spread adoption of $B t$ cotton and insecticide decrease promotes biocontrol services. Nature. 2012;487:362-65. https://doi.org/10.1038/nature11153

124. Whitfield J. Transgenic cotton a winner in India. Nature News Service, Macmillan Magazines Ltd. Feb. 7, 2003.

125. Huang J, Pray C, Rozelle S. Enhancing the crops to feed the poor. Nature. https://doi.org/10.1038/nature01015

126. Ramesh S, Nagadhara D, Reddy VD, Rao KV. Production of transgenic indica rice resistant to yellow stem borer and sap-sucking insects, using super-binary vectors of Agrobacterium tumefaciens. Plant Science. 2004;166:107785. https://doi.org/10.1016/j.plantsci.2003.12.028

127. High SM, Cohen MB, Shu QY, Altosaar I. Achieving successful deployment of $B t$ rice. Trends in Plant Science. 2004;9(6):286-92.

https://doi.org/10.1016/j.tplants.2004.04.002

128. Bashir K, Husnain T, Fatima T, Latif Z, Mehdi S, Riazuddin $\mathrm{S}$. Field evaluation and risk assessment of transgenic indica basmati rice. Molecular Breeding. 2004a;13(4):301-12. https://doi.org/10.1023/B:MOLB.0000034078.54872.25

129. ISAAA. Global Status of Commercialized Biotech/GM Crops in 2017: Biotech Crop Adoption Surges as Economic Benefits Accumulate in 22 Years. ISAAA Brief No. 53. 2017; ISAAA: Ithaca, NY. Available from: http://www.isaaa.org/resources/publications/briefs/53/dow nload/isaaa-brief-53-2017.pdf

130. Palma L, Munoz D, Berry C, Murillo J, Caballero P. Bacillus thuringiensis toxins: an overview of their biocidal activity. Toxins (Basel). 2014:6(12):3296-3325. Published 2014 Dec 11. https://doi.org/10.3390/toxins6123296

131. Sanchis V. From microbial sprays to insect-resistant transgenic plants: History of the biospesticide Bacillus thuringiensis. A review. Agronomy for Sustainable Development. 2011;31:217-31. https://doi.org/10.1051/agro/ 2010027

132. Wang G, Dong Y, Liu X, Yao G, Yu X, Yang M. The Current Status and Development of Insect-Resistant Genetically Engineered Poplar in China. Front Plant Science. 2018; 9:1408. https://doi.org/10.3389/fpls.2018.01408

133. Abramovitch RB, Martin GB. Strategies used by bacterial pathogens to suppress plant defenses. Current Opinion Plant Biology.

https://doi.org/10.1016/j.pbi.2004.05.002

134. Feys BJ, Parker JE. Interplay of signaling pathways in plant disease resistance. Trends in Genetics. 2000;16(10):449-55. https://doi.org/10.1016/S0168-9525(00)02107-7

135. Gurr SJ, Rushton PJ. Engineering plants with increased disease resistance: what are we going to express? Trends in Biotechnology. https://doi.org/10.1016/j.tibtech.2005.04.007

136. Baker B, Zambryski P, Staskawicz B, Dinesh-Kumar SP. Signaling in Plant-Microbe Interactions. Science. 1997;276:726-33.

https://doi.org/10.1126/science.276.5313.726

137. Dangl JL, Jones JD. Nature. 2001;411:826-33. https://doi.org/ $10.1038 / 35081161$

138. Tai TH, Dahlbeck D, Clark ET, Gajiwala P, Pasion R, Whalen MC, et al. Expression of the Bs2 pepper gene confers resistance to bacterial spot disease in tomato. Proceedings of the National Academy of Sciences of the USA. 1999; 96:14153-58. https://doi.org/10.1073/pnas.96.24.14153

139. Rani NS, Prasad GSV, Subba Rao LV, Sudharshan I, Pandey MK, Babu VR, et al. High yielding rice varieties of India Technical bulletin No. 33, Directorate of Rice Research Rajendranagar, Hyderabad 500030, Andhra Pradesh, India. 2008, p. 188

140. Sundaram RM, Vishnupriya MR, Biradar SK, Laha GS, Reddy GA, Rani NS, et al. Marker assisted introgression of bacterial blight resistance in Samba Mahsuri, an elite indica rice variety. Euphytica. 2008;160:411-22. https://doi.org/10.1007/s10681-007-9564-6

141. Wang Y, Xue Y, Li J. Towards molecular breeding and improvement of rice in China. Trends in Plant Science. 2005;10(12):610-14. https://doi.org/10.1016/j.tplants.2005.10.008

142. Kumar V, Chattopadhyay A, Ghosh S, Irfan M, Chakraborty $\mathrm{N}$, Chakraborty S, et al. Improving nutritional quality and fungal tolerance in soyabean and grass pea by expressing an oxalate decarboxylase. Plant Biotechnology Journal. 2016;14:1394-1405. https://doi.org/10.1111/pbi.12503

143. Kesarwani M, Azam M, Natarajan K, Mehta A, Datta A. Oxalate decarboxylase from Collybia velutips: molecular cloning and its over expression to confer resistance to fungal infection in transgenic tobacco and tomato. Journal of Biological Chemistry. 2000;275:7230 38.https://doi.org/10.1074/jbc.275.10.7230

144. Ding SW, Lu R. Virus-derived siRNAs and piRNAs in immunity and pathogenesis. Current Opinion in Virology. 2011;1:533-44. https://doi.org/10.1016/j.coviro.2011.10.028

145. Pelechano V, Steinmetz LM. Gene regulation by antisense transcription. Nature Reviews Genetics. 2013;14:880-93. https://doi.org/10.1038/nrg3594

146. Kamthan A, Kamthan M, Kumar A, Sharma P, Ansari S, Thakur SS, et al. A Calmodulin like EF hand protein positively regulates oxalate decarboxylase expression by interacting with E-box elements of the promoter. Science Reports. 2015;5:14578.https://doi.org/10.1038/srep14578 
147. Otang NV, Kynet K, Khan RS, Ohara M, Goto Y, Wantanabe $\mathrm{M}$, et al. Transgenic tobacco lines expressing defective CMV replicase derived dsRNA are resistant to CMV-O and CMVY. Molecular Biotechnology. 2014;56:50 63.https://doi.org/10.1007/s12033-013-9681-5

148. Peiro A, Canizares MC, Rubio L, Lopez C, Moriones E, Aramburu J, et al. The movement protein (NSm) of Tomato spotted wilt virus is the avirulence determinant in the tomato Sw5 gene-based resistance. Molecular Plant Pathology. 2014;15:802-13. https://doi.org/10.1111/mpp.12142

149. Singh A, Taneja J, Dasgupta I, Mukherjee SK. Development of plants resistant to tomato Gemini viruses using artificial trans-acting small interfering RNA. Molecular Plant Pathology. $\quad 2015$; $\quad 16$ : 724-34 https://doi.org/10.1111/mpp.12229

150. Md. Abul Kalam Azad, Latifah Amin, Nik Marzuki Sidik. Gene Technology for Papaya Ringspot Virus Disease Management. The Scientific World Journal. 2014;11 pages. https://doi.org/10.1155/2014/768038

151. Singh HR, Hazarika P, Agarwala N, Bhatacharjee N, Bhagawati P, Gohain B, et al. Transgenic tea overexpressing Solanum tuberosum endo-1,3-beta-D-glucanase gene conferred resistance against blister blight disease. Plant Molecular Biology Reports. 2018;36:107-22. https://doi.org/10.1007/s11105-017-1063-x

152. Huang LF, Lin KH, He SL, Chen JL, Jiang JZ, Chen BH, et al. Multiple patterns of regulation and over expression of a ribonuclease-like pathogenesis-related protein gene, OsPR10a, conferring disease resistance in rice and Arabidopsis. PLOS ONE. 2016;11, e0156414. https://doi.org/10.1371/journal.pone.0156414

153. Vasavirama K, Kirti PB. Constitutive expression of a fusion gene comprising Trigonella foenum-graecum defensin (Tfgd2) and Raphanus sativus antifungal protein (RsAFP2) confers enhanced disease and insect resistance in transgenic tobacco. Plant Cell Tissue Organ culture. 2013;115:309-19. https://doi.org/10.1007/s11240-013-0363-6

154. Vasavirama K, Kirti PB. Increased resistance to late leaf spot disease in transgenic peanut using a combination of PR genes. Functional Integrated Genomics. 2012;12:625634. https://doi.org/10.1007/s10142-012-0298-8

155. Verberne MC, Verpoorte R, Bol JF, Mercado-Blanco J, Linthorst HJM. Overproduction of salicylic acid in plants by bacterial transgenes enhances pathogen resistance. Nature $\begin{array}{llll}\text { Biotechnology. } & 2000 ; & \text { 78: }\end{array}$ https://doi.org/10.1038/77347

156. Mourgues F, Brisset M, Chevreau E. Activity of different antibacterial peptides on Erwinia amylovora growth, and evaluation of the phytotoxicity and stability of cecropins. Plant Science. 1998;139:83-91. https://doi.org/10.1016/S01689452(98)00178-2

157. Deckard EL. Biotechnology and improved drought tolerance of crops. North Dakota Farm Research 46.1988;16-19.

158. Mullet J. Designing crops for resistance to environmental stress. AgBiotech News and Information 2. 1990;435-36.

159. Toenniessen GH. Potentially useful genes for rice genetic engineering. In: Khush GS, Toenniessen GH, editorss. Rice biotechnology. Wallingford: CABI Publishing; 1991;253-80.

160. Edgerton MD. Increasing crop productivity to meet global needs for feed, food, and fuel. Plant Physiology. 2009;149:713. https://doi.org/10.1104/pp.108.130195

161. Japan. Japan Meteorological Agency. Climate change monitoring report 2014 [Internet]. Canberra: The Department; [updated 2015 Sep] Available from: http://www.jma.go.jp>jma>NMHS>ccmr >ccmr2014 low

162. Japan. Japan Meteorological Agency. Climate change monitoring report 2013 [Internet]. Canberra: The Department; [updated 2014 Sep] Available from: http://www.jma.go.jp $>$ jma $>$ NMHS $>$ ccmr $>c c m r 2013$ low

163. Boyer JS. Plant Productivity and Environment. Science. 1982;218:443-48.

https://doi.org/10.1126/science.218.4571.443
164. Barnes GT. The potential for monolayers to reduce the evaporation of water from large water storages. Agricultural Water Management. 2008;95(4):339-53. https:// doi.org/10.1016/j.agwat.2007.12.003

165. Bray EA, Bailey-Serres J, Weretilnyk E. In: Biochemistry and molecular biology of plants, Gruissem W et al. Editors. Am. Soc. Plant Physiol., Rockville, MD. 2000, 1158-1249.

166. Munns R. Genes and salt tolerance: bringing them together. New Phytologist. 2005;167:645-63. https://doi.org/10.1111/j.1469-8137.2005.01487.x

167. Kondrak M, Marincs F, Antal F, Juhasz Z, Banfalvi Z. Effects of yeast trehalose-6-phosphate synthase 1 gene expression and carbohydrate contents of potato leaves under drought stress conditions. BMC Plant Biology. 2012;12:74-86. https:// doi.org/10.1186/1471-2229-12-74

168. Geilfus C, Zorb C, Muhling K. Salt stress differentially affects growth-mediating $\beta$-expansins in resistant and sensitive maize (Zea mays L.). Plant Physiology and Biochemistry. https://doi.org/10.1016/j.plaphy.2010.09.011

169. Wang W, Vinocur B, Altman A. Plant responses to drought, salinity and extreme temperatures: towards genetic engineering for stress tolerance. Planta. 2003;218:1-14. https://doi.org/10.1007/s00425-003-1105-5

170. Cushman JC, Bohnert HJ. Genomic approaches to plant stress tolerance. Current Opinion in Plant Biology. 2000;3:117-24. https://doi.org/10.1016/S1369-5266(99)00052$\underline{7}$

171. Ingram J, Bartels D. The molecular basis of dehydration tolerance in plants. Annual Reviews of Plant Physiology and Plant Molecular Biology. 1996;47:377-403. https://doi.org/10.1146/annurev.arplant.47.1.377

172. Hasegawa PM, Bressan RA, Zhu JK, Bohnert HJ. Plant cellular and molecular responses to high salinity. Annual Review of Plant Physiology and Plant Molecular Biology. 2000;51:463-99. https://doi.org/10.1146/annurev.arplant.51.1.463

173. Zhu JK. Salt and drought stress signal transduction in plants. Annual Reviews of Plant Biology. 2002;53:247-73. https://doi.org/10.1146/annurev.arplant.53.091401.143329

174. Chinnusamy V, Schumaker K, Zhu JK. Molecular genetic perspectives on cross-talk and specificity in abiotic stress signalling in plants. Journal of Experimental Botany. 2004;55:225-36. https://doi.org/10.1093/jxb/erh005

175. Valliyodan B, Nguyen HT. Understanding regulatory networks and engineering for enhanced drought tolerance in plants. Current Opinion in Plant Biology. 2006;9:189-95. https://doi.org/10.1016/j.pbi.2006.01.019

176. Shinozaki K, Yamaguchi-Shinozaki K. Molecular responses to dehydration and low temperature: differences and cross-talk between two stress signaling pathways.Current Opinion in Plant Biology. 2000;3(3):217-23. https://doi.org/10.1016/S1369-5266(00)00067-4

177. Reguera M, Peleg Z, Blumwald E. Targeting, metabolic pathways for genetic engineering abiotic stress-tolerance in crops. Biochimica et Biophysica Acta (BBA) - Gene Regulatory Mechanisms. 2012;1819(2):186-94. https://doi.org/10.1016/j.bbagrm.2011.08.005

178. ISAAA. Global Status of Commercialized Biotech/GM Crops: 2016. ISAAA Brief No. 52. 2016; ISAAA: Ithaca, NY Available from: http://www.isaaa.org/resources/publications/briefs/52/dow nload/isaaa-brief-52-2016.pdf

179. Monsanto-Company. Petition for the determination of nonregulated status for MON 87460, 2009 www.aphis.usda.gov/biotechnology/not reg.html

180. Castiglioni P, Warner D, Bensen RJ, Anstrom DC, Harrison J, Stoecker M, et al. Bacterial RNA chaperones confer abiotic stress tolerance in plants and improved grain yield in maize under water-limited conditions. Plant Physiol. 2008;147:446-55. https://doi.org/10.1104/pp.108.118828

181. Deikman J, Petracek M, Heard JE. Drought tolerance through biotechnology: improving translation from the laboratory to farmers' fields. Current Opinion in 
Biotechnology. https://doi.org/10.1016/j.copbio.2011.11.003

182. Hu H, Dai M, Yao J, Xiao B, Li X, Zhang Q, et al. Over expressing a NAM, ATAF, and CUC (NAC) transcription factor enhances drought resistance and salt tolerance in rice. Proceedings of the National Academy of Sciences of the United States of America. 2006;103(35):12987-92. https:// doi.org/10.1073/pnas.0604882103

183. Park S, Li J, Pittman JK, Berkowitz GA, Yang H, Undurraga $\mathrm{S}$, et al. Up-regulation of a $\mathrm{H}^{+}$-pyrophosphatase ( $\mathrm{H}^{+}$-PPase) as a strategy to engineer drought-resistant crop plants. Proceedings of the National Academy of Sciences, USA. 2005;102:18830-35. https://doi.org/10.1073/pnas.0509512102

184. Gaxiola RA, Li J, Undurraga S, Dang LM, Allen GJ, Alper SL, et al. Drought- and salt-tolerant plants result from overexpression of the AVP1 $\mathrm{H}^{+}$-pump. Proceedings of the National Academy of Sciences of the United States of America. https://doi.org/10.1073/pnas.191389398

185. Sharma D, Anshuman S. Salinity Research in IndiaAchievements, challenges and Future Prospects. Water and Energy International. 2015;58(6):35-45

186. Zhu JK. Plant salt tolerance. Trends in Plant Science. 2001;6:66-71. https://doi.org/10.1016/S1360-1385(00)01838-0

187. Hsieh TH, Lee JT, Charng YY, Chan MT. Tomato plants ectopically expressing Arabidopsis CBF1 show enhanced resistance to water deficit stress. Plant Physiology.2002;130:618-26. https://doi.org/10.1104/pp.006783

188. Hong Z, Lakkineni K, Zhang K, Verma DPS. Removal of feedback inhibition of delta-pyrroline-5- carboxylate synthase results in increased proline accumulation and protection of plants from osmotic stress. Plant Physiology. 2000;122:1129-36. https://doi.org/10.1104/pp.122.4.1129

189. Yamanouchi U, Yano M, Lin H, Ashikari M, Yamada K. A rice spotted leaf gene, Sp17,encodes a heat stress transcription factor protein. Proceedings of the National Academy of Sciences of the United States of America. 2002;99(11):7530-35. https://doi.org/10.1073/pnas.112209199

190. Jaglo KR, Kleff S, Amunsen KL, Zhang X, Haake V, Zhang JZ, et al. Thomas how MF. Components of Arabidopsis Crepeat/dehydration response element binding factor or cold-response pathway are conserved in Brasicca napus and other plant species. Plant Physiology. 2001;127:910-17. https://doi.org/10.1104/pp.010548

191. Yamaguchi T, Blumwals E. Developing salt tolerant crop plants: Challenges and opportunities. Trends in Plant Sciences. https://doi.org/10.1016/j.tplants.2005.10.002

192. Brookes G, Barfoot P. GM crops: the first ten years - global socio-economic and environmental impacts in the first ten years of commercial use. The Journal of Agrobiotechnology Management \& Economics. 2006; 9(3):139-51.

193. Tausz M, Sircelj H, Grill D. The glutathione system as a stress marker in plant ecophysiology: is a stress-response concept valid? Journal of Experimental Botany. 2004;55:1955-62. https://doi.org/10.1093/jxb/erh194

194. Singla-Pareek SL, Reddy MK, Sopory SK. Genetic engineering of the glyoxalase pathway in tobacco leads to enhanced salinity tolerance. Proceedings of the National Academy of Sciences of the United States of America.2003;100:14672-77. https://doi.org/10.1073/pnas.2034667100

195. Singla-Pareek SL, Yadav SK, Pareek A, Reddy MK, Sopory SK. Transgenic tobacco over-expressing glyoxalase pathway enzymes grow and set viable seeds in zinc-spiked soils.Plant Physiology. 2006;140:613-23. https://doi.org/10.1104/pp.105.073734

196. Singla-Pareek SL, Yadav SK, Pareek A, Reddy MK, Sopory SK. Enhancing salt tolerance in a crop plant by overexpression of glyoxalase II. Transgenic Research. 2008;17:171-80. https://doi.org/10.1007/s11248-007-9082-2
197. Asif MA, Zafar Y, Iqbal J, Iqbal MM, Rashid U, Ali GM, et al. Enhanced expression of AtNHX1, in transgenic groundnut (Arachis hypogaea L.) improves salt and drought tolerence. Molecular Biotechnology. 2011;49:250-56 https://doi.org/10.1007/s12033-011-9399-1

198. Guo YH, Yu YP, Wang D, Wu CA, Yang GD, Huang JG, et al. GhZFP1, a novel CCCH-type zinc finger protein from cotton, enhances salt stress tolerance and fungal disease resistance in transgenic tobacco by interacting with GZIRD21A and GZIPR5. The New phytologist. 2009;183:62-75. https://doi.org/10.1111/j.1469-8137.2009.02838.x

199. FAOSTAT. Food and Agriculture Organization of the United Nations, Rome, Italy. 2017.

200. Sasidharan R, Bailey-Serres J, Ashikari M, Atwell BJ, Colmer TD, Fagerstedt K, et al. Community recommendations on terminology and procedures used in flooding and low oxygen stress research.New Phytol. 2017;214:1403-07. https://doi.org/10.1111/nph.14519

201. Lee SC, Mustroph A, Sasidharan R, Vashisht D, Pedersen O, Oosumi T, et al. Molecular characterization of the submergence response of the Arabidopsis thaliana ecotype Columbia.New Phytologist. 2011;190:457-71. https://doi.org/ 10.1111/j.1469-8137.2010.03590.x

202. Mukhopadhyay A, Minhas D, Grover A. Callusing from rice root explants: adventitious root formation precedes callus initiation response. Current Science. 1997;73(5):465-69.

203. Minhas DA, Grover A. Towards developing transgenic rice plants tolerant to flooding stress. In: Proceedings of the Indian National Science Academy. 1999;65:33-50.

204. Dennis ES, Dolferus R, Ellis M, Rahman M, Wu Y, Hoeren FU, et al. Molecular strategies for improving waterlogging tolerance in plants. Journal of Experimental Botany. 2000;51(342):89-97. https://doi.org/10.1093/jexbot/51.342.89

205. Qunimio CA, Torrizo LB, Setter TL, Elllis M, Grover A, Abrigo EM, et al. Enhancement of submergence tolerance in transgenic rice overproducing pyruvate decarboxylase. J Plant Physiology. 2000;156:516-21. https://doi.org/10.1016/S0176-1617(00)80167-4n

206. Musrur R, Anil G, Peacock W, Elizabeth D, Marc E. Effects of manipulation of pyruvate decarboxylase and alcohol dehydrogenase levels on the submergence tolerance of rice. Functional Plant Biology. 2001;28:1231-41. https://doi.org/10.1071/PP00137

207. Dennis ES, Dolferus R, Ellis M, Rahaman M, Wu Y, Hoeren FU, et al. Molecular strategies for improving water logging tolerance in plants. Journal of Experimental Botany. 2000;51:89-97. https://doi.org/10.1093/jexbot/51.342.89

208. Levitt J. Responses of Plants to Environmental Stresses, p.497.1980; Academic Press, New York.

209. Steponkus PL. Role of the Plasma Membrane in Freezing Injury and Cold Acclimation Annual Review of Plant Physiology.1984;35(1):543-84. https://doi.org/10.1146/annurev.pp.35.060184.002551

210. Steponkus PL, Uemura M, Webb MS. A contrast of the cryostability of the plasma membrane of winter rye and spring oat-two species that widely differ in their freezing tolerance and plasma membrane lipid composition. In Steponkus PL, Ed. Advances in Low-Temperature Biology. Vol. 2. London: JAI Press, Ltd.;1993.p. 211-312.

211. Hajela RK, Horvath DP, Gilmour SJ, Thomashow MF. Molecular cloning and expression of cor (cold regulated) genes in Arabidopsis thaliana. Plant Physiology. 1990;93:1246-52. https://doi.org/10.1104/pp.93.3.1246

212. Gilmour SJ, Sebolt AM, Salazar MP, Everard JD, Thomashow MF. Overexpression of the ArabidopsisCBF3 transcriptional activator mimics multiple biochemical changes associated with cold acclimation. Plant Physiology. 2000;124:1854-65. https://doi.org/10.1104/pp.124.4.1854

213. Kasuga M, Liu Q, Miura S, Yamaguchi-Shinozaki K, Shinozaki K. Improving plant drought, salt and freezing tolerance by gene transfer of a single stress-inducible transcription factor. Nature Biotechnology. 1999;17:287-91. https://doi.org/10.1038/7036 
214. Jaglo-Ottosen KR, Gilmour SJ, Zarka DG, Schabenberger O, Thomashow MF. Arabidopsis CBF1 overexpression induces COR genes and enhances freezing tolerance. Science. 1998;280:104-06. https://doi.org/10.1126/science.280.5360.104

215. Liu Q, Ksauga M, Sakuma Y, Abe H, Miura S, YamaguchiShinozaki K, et al. Two transcription factors, DREB1 and DREB2, with an EREBP/AP2 DNA binding domain separate two cellular signal transduction pathways in drought and low-temperature-responsive gene expression, respectively, in Arabidopsis. Plant cell. 1998;10:1391-1406. https://doi.org/10.1105/tpc.10.8.1391

216. Hsieh TH, Lee JT, Yang PT, Chiu LH, Charng YY, Wang YC, et al. Heterology expression of the Arabidopsis C-repeat/dehydration response element binding factor 1 gene confers elevated tolerance to chilling and oxidative stresses in transgenic tomato. Plant Physiology. 2002;129:1086-94. https://doi.org/10.1104/pp.003442

217. Kim JS, Park SJ, Kwak KJ, Kim YO, Kim JY, Song J, et al. Cold shock domain proteins and glycine-rich RNA-binding proteins from Arabidopsis thaliana can promote the cold adaptation process in Escherichia coli. Nucleic Acids Research https://doi.org/10.1093/nar/gkl1076

218. Dai X, Xu Y, Ma Q, Xu W, Wang T, Xue Y, et al. Over expression of an R1R2R3 MYB gene, OsMYB3R-2, increases tolerance to freezing, drought and salt stress in transgenic Arabidopsis. Plant Physiology 2007;143:1739-51. https://doi.org/10.1104/pp.106.094532

219. Kim YO, Kim JS, Kang H. Cold-inducible zinc fingercontaining glycine-rich RNA-binding protein contributes to the enhancement of freezing tolerance in Arabidopsis thaliana. Plant J. 2005;42:890-900. https://doi.org/10.1111/j.1365-313X.2005.02420.x

220. Dong CH, Hu X, Tang W, Zheng X, Kim YS, Lee B, et al. A putative Arabidopsis nucleoporin, AtNUP160, is critical for RNA export and required for plant tolerance to cold stress. Molecular Cellular Biology. 2006;26:9533-43. https://doi.org/ 10.1128/MCB.01063-06

221. Pramanik MH, Imai R. Functional identification of a trehalose 6-phosphate phosphatase gene that is involved in transient induction of trehalose biosynthesis during chilling stress in rice. Plant Molecular Biology. 2005;58:75162. https://doi.org/10.1007/s11103-005-7404-4

222. Garg AK, Kim JK, Owens TG, Ranwala AP, Choi YD, Kochian $\mathrm{LV}$, et al. Trehalose accumulation in rice plants confers high tolerance levels to different abiotic stresses. Proceedings of the National Academy of Sciences of the United States of America.2002;99(25):15898-903. https://doi.org/10.1073/pnas.252637799

223. Jang IC, Oh SJ, Seo JS, Choi WB, Song SI, Kim CH, et al. Expression of a bi-functional fusion of the Escherichia coli genes for trehalose-6-phosphate synthase and trehalose- 6phosphate phosphatase in transgenic rice plants increases trehalose accumulation and abiotic stress tolerance without stunting growth. Plant Physiology. 2003;131:51624. https://doi.org/10.1104/pp.007237

224. Ge LF, Chao DY, Shi M, Zhu MZ, Gao JP, Lin HX. Overexpression of the trehalose-6-phosphate phosphatase gene OsTPP1 confers stress tolerance in rice and results in the activation of stress responsive genes. Planta. 2008;228:191201. https://doi.org/10.1007/s00425-008-0729-x

225. Iordachescu M, Imai R. Trehalose biosynthesis in response to abiotic stresses. J. Integr Plant Biol 2008;50:1223-29. https://doi.org/10.1111/j.1744-7909.2008.00736.x

226. Verma C, Nanda S, Singh RK, Singh RB, Mishra S. A review on impacts of genetically modified food on human health. The Open Nutraceuticals Journal. 2011;4:3-11. https://doi.org/10.2174/1876396001104010003

227. Alberts B. Standing up for GMOs. Science. 2013;341(6152):1320. https://doi.org/10.1126/science.1245017

228. World health statistics overview. Monitoring health for the SDGs, sustainable development goals. Geneva
(Switzerland). [Internet]. WHO; 2019. Available from: https://www.who.int>gho>world health statistics $>2019$

229. Potrykus I. The 'Golden Rice' tale. In Vitro Cellular \& Developmental Biology-Plant. 2001;37:93-100. https://doi.org/10.1007/s11627-001-0019-9

230. Goldbas A. GMOS: what are they? International Journal of Childbirth Education. 2014;29(3):20.

231. Lucas DM, Tailor ML, Hartnell GF, Nemeth MA, Glenn KC, Davis SW. Broiler performance and carcass characteristics when fed diets containing lysine maize (LYS038) or LYO38 $x$ MON 810), control of conventional reference maize. Poultry Science. 2007;86:2152-61. https://doi.org/10.1093/ps/ $\underline{86.10 .2152}$

232. He XY, Tang MZ, Luo YB, Li X, Cao SS, Yu JJ, et al. A 90-day toxicology study of transgenic lysine-rich maize grain (Y642) in Sprague-Dawley rats. Food and Chemical Toxicology. https://doi.org/10.1016/j.fct.2008.11.032

233. Edwards HM, Douglas MW, Parsons CM, Baker DH. Protein and energy evaluation of soybean meals processed from genetically modified high-protein soybeans. Poultry Science. 2000;79:525-27. https://doi.org/10.1093/ps/79.4.525

234. Ravindran V, Tabe LM, Molvig L, Higgins TZV, Bryden WL. Nutritional evaluation of transgenic high-methionine lupins (Lupinus angustifolius) with broiler chickens. Journal of the Science of Food and Agriculture.2002;82:280 85. https://doi.org/10.1002/jsfa.1030

235. Poirier Y. Production of polyesters in transgenic plants. Advances in Biochemical Engineering/Biotechnology. 2001;71:209-240. https://doi.org/10.1007/3-540-40021-4 7

236. Hiatt A, Pauly M. Monoclonal antibodies from plants: a new speed record. Proceedings of the National Academy of Sciences of the United States of America.2006;103:14645-46. https://doi.org/10.1073/pnas.0607089103

237. Stoger E, Sack M, Nicholson L, Fischer R, Christou P. Recent progress in plantibody technology. Current Pharmaceutical Design. https://doi.org/10.2174/1381612054367535

238. Dyer JM, Stymne S, Green AG, Carlsson AS. High-value oils from plants. Plant Journal. 2008;54:640-55. https://doi.org/10.1111/j.1365-313X.2008.03430.x

239. Damude HG, Kinney AJ. Enhancing plant seed oils for human nutrition. Plant Physiology. 2008;147:962-68. https:// doi.org/10.1104/pp.108.121681

240. Avise JC. The Hope, Hype, and Reality of Genetic Engineering: remarkable stories from agriculture, industry, medicine, and the environment. Oxford University press; 2004.

241. Houwat I, Osowski V. MSU scientists work to make biodegradable plastic from sunlight. Environment + Science \& Technology [Internet]. 2017 Oct 26. Available from: https://msutoday.msu.edu/news/2017/msu-scientistswork-to-make-biodegradable-plastic-from-sunlight

242. Osanai T, Oikawa A, Numata K, Kuwahara A, Ijijima H, Doi Y, et al. Pathway-level acceleration of glycogen catabolism by response regulator in the Cyanobacterium Synechocystis sp. PCC 6803. Plant Physiology. 2014;164(4):1831-41 https://doi.org/10.1104/pp.113.232025

243. Ma JKC, Hein MB. Antibody production and engineering in plants. In: Collins GB \& Shepherd RJ (eds) Engineering Plants for Commercial Products and Applications.1996;792:72-81. https://doi.org/10.1111/j.17496632.1996.tb32493.x

244. Cabanes-Macheteau M, Fitchette-Laine AC, LoutelierBourhis C, Lange C, Vine N, Ma J, et al. N-Glycosylation of a mouse IgG expressed in transgenic tobacco plants. Glycobiology. 1999;9:365-72. https://doi.org/10.1093/glycob/ 9.4.365

245. Tackett CO, Mason HS. A review of oral vaccination with transgenic vegetables. Microbes and Infection. 1999;1:77783. https://doi.org/10.1016/S1286-4579(99)80080-X

246. Della-Cioppa G, Grill LK. Production of novel compounds in higher plants by transfection with RNA viral vectors. In 
Collins GB, Sheperd RJ, editors. Engineering plants for commercial products and applications, New York Academy of Sciences, NY 1996, p.57-61. https://doi.org/10.1111/j.17496632.1996.tb32491.x

247. Hiatt AC, Cafferkey R, Bowdish K. Production of antibodies in plants. Nature. 1989;42:6-78

248. Dalsgaard K, Uttenthal A, Jones TD, Xu F, Merryweather A, Hamilton WDO, et al. Plant-derived vaccine protects target animals against a viral disease. Nature Biotechnology. 1997;15:248-52. https://doi.org/10.1038/nbt0397-248

249. Mushegian AR, Shepard RJ. Genetic elements of plant viruses as tools for genetic engineering. Microbiology. Reviews. 1995;59:548-78.

250. Beachy RN, Fitchen JH, Hein MB. Use of plant viruses for delivery of vaccine epitopes, In: Collins GB, Sheperd RJ, editors. Engineering plants for commercial products and applications, New York Academy of Sciences, NY;1996:4349. https://doi.org/10.1111/j.1749-6632.1996.tb32489.x

251. Fischer R, Twyman RM, Schillberg S. Production of antibodies in plants and their use for global health. Vaccine. 2003;21:820-25. https://doi.org/10.1016/S0264410X(02)00607-2

252. Barta A, Sommergruber K, Thompson D, Hartmuth K, Matzke MA, Matzke AJM. The expression of a nopaline synthase human growth hormone chimeric gene in transformed tobacco and sunflower callus tissue. Plant Molecular $\quad$ Biology. 1986;6:347-57. https://doi.org/10.1007/BF00034942

253. Lico C, Santi L, Twyman RM, Pezzotti M, Avesani L. The use of plants for the production of therapeutic human peptides. Plant Cell Reports.2012;31:439-51. https://doi.org/ 10.1007/s00299-011-1215-7

254. Merlin M, Gecchele E, Capaldi S, Pezzotti M, Avesani L. Comparative evaluation of recombinant protein production in different biofactories: the green perspective. BioMed Research International. 2014; Article ID 136419, 14 pages. https://doi.org/10.1155/2014/136419

255. Twyman RM, Schillberg S, Fischer R. Transgenic plants in the biopharmaceutical market. Expert Opinion on Emerging Drugs. 2005;10:185-218. https://doi.org/10.1517/14728214.10.1.185

256. Shoseyov O, Posen Y, Grynspan F. Human collagen produced in plants, more than just another molecule. Bioengineered. https://doi.org/10.4161/bioe.26002

257. Hennegan K, Yang D, Nguyen D, Wu L, Goding J, Huang J, et al. Improvement of human lysozyme expression in transgenic rice grain by combining wheat (Triticum aestivum) puroindoline $\mathrm{b}$ and rice (Oryza sativa) Gt1 promoters and signal peptides. Transgenic Research. 2005;14:583-92. https://doi.org/10.1007/s11248-004-6702-y

258. Yang D, Guo F, Liu B, Huang N, Watkins S. Expression and localization of human lysozyme in the endosperm of transgenic rice. Planta. 2002;216:597-603. https://doi.org/10.1007/s00425-002-0919-x

259. Van Dussen L, Zimran A, Akkerman E, Aerts J, Petakov M, Elstein D, et al. Taliglucerase alfa leads to favorable bone marrow responses in patients with type I Gaucher disease. Blood Cells, Molecules, and Diseases. 2013;50:206-11. https://doi.org/10.1016/j.bcmd.2012.11.001

260. Zimran A, Brill-Almon E, Chertkoff R, Petakov M, BlancoFavela F, Munoz E, et al. Pivotal trial with plant cellexpressed recombinant glucocerebrosidase, taliglucerase alfa, a novel enzyme replacement therapy for Gaucher $\begin{array}{lll}\text { disease. } & \text { Blood. 2011;118:5767-73. }\end{array}$ https://doi.org/10.1182/blood-2011-07-366955

261. Giddings G, Allison G, Brooks D, Carter A. Transgenic plants as factories for biopharmaceuticals. Nature Biotechnology. https://doi.org/10.1038/81132

262. Mason HS, Arntzen CJ. Transgenic plants as vaccine production systems. Trends in Biotechnology. 1995;13:38892. https://doi.org/10.1016/S0167-7799(00)88986-6
263. Walmsley AM, Arntzen CJ. Plants for delivery of edible vaccines. Current Opinion in Biotechnology. 2000;11:126129. https://doi.org/10.1016/S0958-1669(00)00070-7

264. Saxena J, Rawat S. Edible vaccines. Advances in Biotechnology. 2014;207-26. https://doi.org/10.1007/978-81322-1554-7 12

265. Penney CA, Thomas DR, Deen SS, Walmsley AM. Plantmade vaccines in support of the Millennium Development Goals. Plant Cell Reports. 2011;30(5):789-98. https://doi.org/10.1007/s00299-010-0995-5

266. Aboul-Ata AAE, Vitti A, Nuzzaci M, El-Attar AK, Piazzolla G, Tortorella C, et al. Plant-based vaccines: novel and low-cost possible route for mediterranean innovative vaccination strategies. Advances in Virus Research. 2014;89:1-37. https://doi.org/10.1016/B978-0-12-800172-1.00001-X

267. Kim MY, Yang MS, Kim TG. Expression of dengue virus e glycoprotein domain III in non-nicotine transgenic tobacco plants," Biotechnology and Bioprocess Engineering. 2009;14(6):725-30. https://doi.org/10.1007/s12257-009-3011-6

268. Guan ZJ, Guo B, Huo YL, Guan ZP, Dai JK, Wei YH. Recent advances and safety issues of transgenic plant derived vaccines. Applied Microbiology and Biotechnology. 2013;97(7):2817-40. https://doi.org/10.1007/s00253-012-45662

269. Joshi SG, Schaart JG, Groenwold R, Jacobsen E, Schouten HJ, Krens FA. Functional analysis and expression profiling of HcrVf1 and HcrVf2 for development of scab resistant cisgenic and intragenic apples. Plant Molecular Biology. 2011;75:579-91. https://doi.org/10.1007/s11103-011-9749-1

270. Weeks JT, Ye J, Rommens CM. Development of an in planta method for transformation of alfalfa (Medicago sativa). Transgenic Research. 2008;17:587-97. https://doi.org/10.1007/s11248-007-9132-9

271. Rommens CM, Yan H, Swords K, Richael C, Ye J. Low acrylamide French fries and potato chips. Plant Biotechnology Journal. 2008;6:843-53. https://doi.org/10.1111/j.1467-7652.2008.00363.x

272. Holme IB, Dionisio G, Brinch-Pedersen H, Wendt T, Madsen CK, Vincze E, et al. Cisgenic barley with improved phytase activity. Plant Biotechnology Journal. 2012;10: 237-47. https://doi.org/10.1111/j.1467-7652.2011.00660.x

273. Haverkort AJ, Struik PC, Visser RGF, Jacobsen E. Applied biotechnology to combat late blight in potato caused by Phytophthora infestans. Potato Research. 2009;52:249-64. https://doi.org/10.1007/s11540-009-9136-3

274. Gadaleta A, Giancaspro A, Blechl AE, Blanco A. A transgenic durum wheat line that is free of marker genes and expresses 1DY10. Journal of Cereal Science. 2008;48:439-45. https://doi.org/10.1016/j.jcs.2007.11.005

275. Qi Y, Li X, Zhang Y, Starker CG, Baltes NJ, Zhang F, et al. Targeted deletion and inversion of tandemly arrayed genes in Arabidopsis thaliana using zinc finger nucleases. G3 Genes, Genomes, Genetics. 2013;3:1707-15. https://doi.org/10.1534/g3.113.006270

276. Curtin SJ, Zhang F, Sander JD, Haun WJ, Starker C, Baltes NJ, et al. Targeted mutagenesis of duplicated genes in soybean with zinc-finger nucleases. Plant Physiology. 2011;156:466-73. https://doi.org/10.1104/pp.111.172981

277. Zhang F, Maeder ML, Unger-Wallace E, Hoshaw JP, Reyon D, Christian M, et al. High frequency targeted mutagenesis in Arabidopsis thaliana using zinc finger nucleases. Proceedings of the National Academy of Sciences of the United States of America.2010;107:12028-33. https://doi.org/ 10.1073/pnas.0914991107

278. Shukla KV, Doyon Y, Miller JC, DeKelver RC, Moehle EA, Worden SE, et al. Precise genome modification in the crop species Zea mays using zinc-finger nucleases. Nature. 2009;459:437-41. https://doi.org/10.1038/nature07992

279. Cantos C, Francisco P, Trijatmiko KR, Slamet-Loedin I, Chadha-Mohanty PK. Identification of "safe harbor" loci in indica rice genome by harnessing the property of zincfinger nucleases to induce DNA damage and repair. Frontiers in Plant Science. 2014;5: 302 https://doi.org/10.3389/fpls.2014.00302 
280. Wendt T, Holm PB, Starker CG, Christian M, Voytas DF, Henrik Brinch-Pedersen, et al. TAL effector nucleases induce mutations at a pre-selected location in the genome of primary barley transformants. Plant Molecular Biology. 2013;83:279-85. https://doi.org/10.1007/s11103-013-0078-4

281. Haun W, Coffman A, Clasen BM, Demorest ZL, Lowy A, Ray $\mathrm{E}$, et al. Improved soybean oil quality by targeted mutagenesis of the fatty acid desaturase 2 gene family. Plant Biotechnology. https://doi.org/10.1111/pbi.12201

282. Hyeong JJ, Walid F, WilfreD V, Maria G, Fredy A. RNAi suppression of lignin biosynthesis in sugarcane reduces recalcitrance for biofuel production from lignocellulosic biomass. Plant biotechnology journal. 2012; 10. https://doi.org/10.1111/j.1467-7652.2012.00734.x

283. Qiu JL. Simultaneous editing of three homoeoalleles in hexaploid bread wheat confers heritable resistance to powdery mildew. Nature Biotechnology. 2014;32:947-51. https://doi.org/10.1038/nbt.2969

284. Gao H, Smith J, Yang M, Jones S, Djukanovic V, Nicholson MG, et al. Heritable targeted mutagenesis in maize using a designed endonuclease. Plant Journal. 2010;61:176-87. https://doi.org/10.1111/j.1365-313X.2009.04041.x

285. Djukanovic V, Smith J, Lowe K, Yang M, Gao H, Jones S, et al. Male-sterile maize plants produced by targeted mutagenesis of the cytochrome P450-like gene (MS26) using a re-designed I-CreI homing endonuclease. Plant Journal. 2013;76:888-99. https://doi.org/10.1111/tpj.12335

286. Jiang W, Zhou H, Bi H, Fromm M, Yang B, Weeks DP. Demonstration of CRISPR/Cas9/sgRNA-mediated targeted gene modification in Arabidopsis, tobacco, sorghum and rice. Nucleic Acids Research. 2013;41:e188. https://doi.org/10.1093/nar/gkt780

287. Li JF, Norville JE, Aach J, McCormack M, Zhang D, Bush J, et al. Multiplex and homologous recombination-mediated genome editing in Arabidopsis and Nicotiana benthamiana using guide RNA and Cas9. Nature Biotechnology. 2013;31:688-91. https://doi.org/10.1038/nbt.2654

288. Feng Z, Mao Y, Xu N, Zhang B, Wei P, Yang DL, et al. Multigeneration analysis reveals the inheritance, specificity, and patterns of CRISPR/Cas-induced gene modifications in Arabidopsis. Proceedings of the National Academy of Sciences of the United States of America. 2014;111:4632-37. https://doi.org/10.1073/pnas.1400822111

289. Shan Q, Wang Y, Li J, Zhang Y, Chen K, Liang Z, et al. Targeted genome modification of crop plants using a CRISPR-Cas system. Nature Biotechnology. 2013;31: 686-88. https://doi.org/10.1038/nbt.2650

290. Jia H, Wang N. Targeted genome editing of sweet orange using Cas9/sgRNA. PLoS One 2014;9:e93806. https://doi.org/ 10.1371/journal.pone.0093806

291. Sun Y, Jiao G, Liu Z, Zhang X, Li J, Guo X, et al. Generation of High-Amylose Rice through CRISPR/Cas9-Mediated Targeted Mutagenesis of Starch Branching Enzymes. Frontiers in Plant Science. 2017;8. https://doi.org/10.3389/fpls.2017.00298

292. Zhang Y, Bai Y, Wu G, Zou S, Chen Y, Gao C, et al Simultaneous modification of three homoeologs of TaEDR1 by genome editing enhances powdery mildew resistance in wheat. Plant Journal. 2017;91(4):714-24. https://doi.org/10.1111/tpj.13599

293. Geibler R, Scholze H, Hahn S, Streubel J, Bonas U, Behrens SE, et al. Transcriptional activators of human genes with programmable DNA-specificity. PLoS One. 2011;6:e19509. https://doi.org/10.1371/journal.pone.0019509

294. Mahfouz MM, Li L, Piatek M, Fang X, Mansour H, Bangarusamy DK, et al. Targeted transcriptional repression using a chimeric TALE-SRDX repressor protein. Plant Molecular Biology. https://doi.org/10.1007/s11103-011-9866-x
2012;78:311-21 